OPEN ACCESS

Edited by:

Anouschka R. Hof,

Wageningen University \&

Research, Netherlands

Reviewed by:

Timothy Assal,

United States Geological Survey,

United States

Miguel Berdugo,

University of Alicante, Spain

*Correspondence:

John B. Bradford

jbradford@usgs.gov

Jeanne C. Chambers

jeanne.chambers@usda.gov

Specialty section:

This article was submitted to Biogeography and Macroecology,

a section of the journal

Frontiers in Ecology and Evolution

Received: 20 December 2018

Accepted: 09 September 2019

Published: 26 September 2019

Citation:

Bradford JB, Schlaepfer DR

Lauenroth WK, Palmquist KA,

Chambers JC, Maestas JD and Campbell SB (2019) Climate-Driven

Shifts in Soil Temperature and

Moisture Regimes Suggest

Opportunities to Enhance

Assessments of Dryland Resilience and Resistance.

Front. Ecol. Evol. 7:358.

doi: 10.3389/fevo.2019.00358

\section{Climate-Driven Shifts in Soil Temperature and Moisture Regimes Suggest Opportunities to Enhance Assessments of Dryland Resilience and Resistance}

\author{
John B. Bradford ${ }^{1 *}$, Daniel R. Schlaepfer ${ }^{2}$, William K. Lauenroth ${ }^{2,3}$, Kyle A. Palmquist ${ }^{3}$, \\ Jeanne C. Chambers ${ }^{4 *}$, Jeremy D. Maestas ${ }^{5}$ and Steven B. Campbell ${ }^{6}$
}

\begin{abstract}
${ }^{1}$ U.S. Geological Survey, Southwest Biological Science Center, Flagstaff, AZ, United States, ${ }^{2}$ School of Forestry and Environmental Studies, Yale University, New Haven, CT, United States, ${ }^{3}$ Department of Botany, University of Wyoming, Laramie, WY, United States, ${ }^{4}$ United States Department of Agriculture Forest Service, Rocky Mountain Research Station, Reno, NV, United States, ${ }^{5}$ United States Department of Agriculture Natural Resources Conservation Service, Redmond, WA, United States, ${ }^{6}$ United States Department of Agriculture Natural Resources Conservation Service, Portland, OR, United States
\end{abstract}

Assessing landscape patterns in climate vulnerability, as well as resilience and resistance to drought, disturbance, and invasive species, requires appropriate metrics of relevant environmental conditions. In dryland systems of western North America, soil temperature and moisture regimes have been widely utilized as an indicator of resilience to disturbance and resistance to invasive plant species by providing integrative indicators of long-term site aridity, which relates to ecosystem recovery potential and climatic suitability to invaders. However, the impact of climate change on these regimes, and the suitability of the indicator for estimating resistance and resilience in the context of climate change have not been assessed. Here we utilized a daily time-step, process-based, ecosystem water balance model to characterize current and future patterns in soil temperature and moisture conditions in dryland areas of western North America, and evaluate the impact of these changes on estimation of resilience and resistance. Soil temperature increases in the twenty-first century are substantial, relatively uniform geographically, and robust across climate models. Higher temperatures will expand the areas of mesic and thermic soil temperature regimes while decreasing the area of cryic and frigid temperature conditions. Projections for future precipitation are more variable both geographically and among climate models. Nevertheless, future soil moisture conditions are relatively consistent across climate models for much of the region. Projections of drier soils are expected in most of Arizona and New Mexico, as well as the central and southern U.S. Great Plains. By contrast, areas with projections of increasing soil moisture include northeastern Montana, southern Alberta and Saskatchewan, and many areas dominated by big sagebrush, particularly the Central and Northern Basin and Range and the Wyoming Basin ecoregions. 
In addition, many areas dominated by big sagebrush are expected to experience pronounced shifts toward cool season moisture, which will create more area with xeric moisture conditions and less area with ustic conditions. In addition to indicating widespread geographic shifts in the distribution of soil temperature and moisture regimes, our results suggest opportunities for enhancing the integration of these conditions into a quantitative framework for assessing climate change impacts on dryland ecosystem resilience and resistance that is responsive to long-term projections.

Keywords: aridification, big sagebrush ecosystems, cheatgrass, climate change, drought, ecological transformation, vulnerability

\section{INTRODUCTION}

Global change, particularly altered disturbance regimes, biological invasions, and long-term climatic shifts, represent growing challenges for policy makers, and natural resource managers working to sustain ecosystem services (Glick et al., 2010). Among the most important applied information needs to maximize the ability of resource managers to cope with these changes is reliable understanding of geographic patterns in ecosystem vulnerability to climate change and subsequent impacts on ecological resilience (Box 1) to disturbance and other stressors (Briske et al., 2015). Decision makers need a quantitative, systematic way to recognize how locations differ in their expected response to changes in both climate and disturbances. This information would enable efficient prioritization and resource allocation by identifying areas where management activities can increase the adaptive capacity of ecosystems and minimize adverse impacts. It would also identify those areas where important changes in climate are expected and management activities need to focus on assisting ecosystems in transitioning to the new conditions (Millar et al., 2007; Snyder et al., 2018).

The need for insights about geographic patterns of climate vulnerability is especially pronounced in dryland regions, where degradation has been widespread and many ecosystems are heavily dependent on moisture that is acquired in the soil profile (Huang et al., 2017). Persistent land degradation due to combinations of land use, disturbance, and biological invasions, has emerged as one of the most pressing contemporary management challenges in dryland regions (Herrick et al., 2012). The simultaneous increase in the abundance of degraded land and growing land use pressure often impede efforts to sustain or restore dryland ecosystems (Kildisheva et al., 2016). In addition, because rising temperatures are among the most consistent projected aspects of climate change, and higher temperature exacerbates aridity, dryland regions may be especially impacted by climate change (Huang et al., 2017). However, plants in dryland environments respond primarily to soil moisture, not precipitation (Noy-Meir, 1973). As a result, accurately projecting the magnitude, potential implications, and uncertainty of changes in drought stress experienced by dryland ecosystems in response to rising temperature and altered future precipitation patterns is complicated (Wang et al., 2012). Because climatic conditions, edaphic properties, and vegetation feedbacks interact to influence moisture availability, dryland ecosystem vulnerability to climate change and ecological resilience to disturbance are highly heterogeneous in both space and time. This heterogeneity represents a substantial challenge to developing geographically appropriate management strategies that prevent degradation and promote recovery from disturbance.

In the dryland ecosystems that characterize much of western North America, long-term environmental conditions can provide useful insights into ecological resilience to disturbance and resistance to invasive species (Chambers et al., 2014a, 2019a,b). Recent work has applied soil characteristics to describe geographic patterns of disturbance resilience and invasion resistance, specifically cheatgrass (Bromus tectorum), at regional to site scales (Chambers et al., 2016, 2017a,b; Maestas et al., 2016). Specifically, soil temperature and moisture regimes, based on soil taxonomy and mapped by the National Cooperative Soil Survey, were used because they integrate the combined effects of temperature and precipitation to

BOX 1 | Ecological vulnerability, resilience, and resistance.

Vulnerability to climate change: The degree to which a system is susceptible to, and unable to cope with, adverse effects of climate change, including climate variability, and extremes. Vulnerability is a function of climate exposure, the magnitude of expected change in climate mean and variability; sensitivity, the potential ecological impact of changing climate; and adaptive capacity, the ability of a system to maintain critical composition and function as climate changes (Glick et al., 2010; Stein et al., 2014).

Ecological resilience: The amount of change needed to change an ecosystem from one set of processes and structures to a different set of processes and structures or the amount of disturbance that a system can withstand before it shifts into a new regime or alternative stable state (Holling, 1973). In the applied context here, resilience describes the capacity of an ecosystem to regain its fundamental structure, processes, and functioning (or remain largely unchanged) despite stresses and disturbances (Hirota et al., 2011; Chambers et al., 2014a; Seidl et al., 2016).

Ecological resistance: The ability of an ecosystem to stay essentially unchanged despite the presence of disturbances and stressors (Grimm and Wissel, 1997). In the applied context here, resistance describes the attributes and processes of an ecosystem that influence the potential population growth and eventual dominance by an invading species (D'Antonio and Thomsen, 2004). 
characterize overall patterns of soil moisture availability for plant communities and represent estimates of long-term, typical conditions (Soil Survey Staff, 2014). Potential resilience and resistance $(\mathrm{R} \& \mathrm{R})$ varies across environmental gradients and among ecological types and ecological sites (Chambers et al., 2014a). To facilitate broad-scale analyses of resilience and resistance, the dominant ecological types in the sagebrush range were identified and their soil temperature and moisture regime determined. Then resilience and resistance categories were assigned to each ecological type based on available ecological site descriptions and expert knowledge. Soil survey spatial and tabular data were aggregated according to soil temperature and moisture regime and moisture subclass (Maestas et al., 2016). A simplified index of relative resilience and resistance was generated by assigning each soil temperature and moisture regime/moisture subclass to one of three categories (high, moderate, and low) based on the ecological type descriptions and expert input. These simplified categories have provided a useful framework for ecologically-based resource allocation and determination of appropriate management strategies across scales (Maestas et al., 2016; Chambers et al., 2017a,b).

As climatic conditions change, soil temperature and moisture conditions will also change. Soil temperature and moisture regimes are defined by criteria that indicate how temperature and moisture conditions differ among regimes (Soil Survey Staff, 2014). However, current geographic databases for both temperature and moisture regimes are derived from soil surveys that use qualitative approaches, for example indicator plant species, to map the geographic distribution of regimes. As a result, these survey-based methods do not lend themselves to a quantitative assessment of the future distribution of soil temperature and moisture regimes. Projections of future regimes will require a process-based approach in which regimes are systematically linked to driving climatic and edaphic conditions.

Because soil temperature and moisture regimes are currently being incorporated into natural resource planning and management, developing projections for future changes is an important step toward quantifying and understanding uncertainty around climate change impacts. Our overall goal was to assess how projected changes in climate will alter soil temperature and moisture conditions in drylands of western North America. We simulated soil temperature and moisture conditions for current climate, and for future climate represented by all available climate models at two time periods during the twenty-first century. We used the results to: (1) quantify the direction and magnitude of expected changes in several measures of soil temperature and soil moisture, including the key variables used to distinguish the regimes used in the R\&R categories; (2) assess how these changes will impact the geographic distribution of soil temperature and moisture regimes; and (3) explore the implications for using $\mathrm{R} \& \mathrm{R}$ categories for estimating future ecosystem resilience and resistance.

\section{METHODS}

\section{Study Area}

We quantified soil temperature and moisture conditions in dryland areas of the U.S. and Canada where the ratio of mean annual precipitation to potential evapotranspiration was $<0.6$. We simulated conditions on a $10-\mathrm{km}$ resolution grid, resulting in 58,694 cells for the entire dryland extent. Because resilience and resistance concepts are widely developed for big sagebrush ecosystems, we describe results for resilience and resistance metrics only within the Greater Sage-grouse Management Zones (Manier et al., 2013), an area represented by 16,111 cells (Figure S2.1).

\section{Soil Temperature and Moisture Variables Examined}

We quantified current and future conditions for two soil temperature variables (Figure 1) that define soil temperature regimes as defined by the National Cooperative Soil Survey (Soil Survey Staff, 2014): mean annual soil temperature at $50 \mathrm{~cm}$ depth (hereafter $\mathrm{T}_{\mathrm{ANN} 50}$ ), and mean summer (June-August) temperature at $50 \mathrm{~cm}$ depth $\left(\mathrm{T}_{\text {SUM50 }}\right)$. Conditions with $\mathrm{T}_{\mathrm{ANN} 50}<$ 0 are classified as other (primarily permafrost), while increments of $8^{\circ} \mathrm{C}$ separate the remaining soil temperature regimes, with the

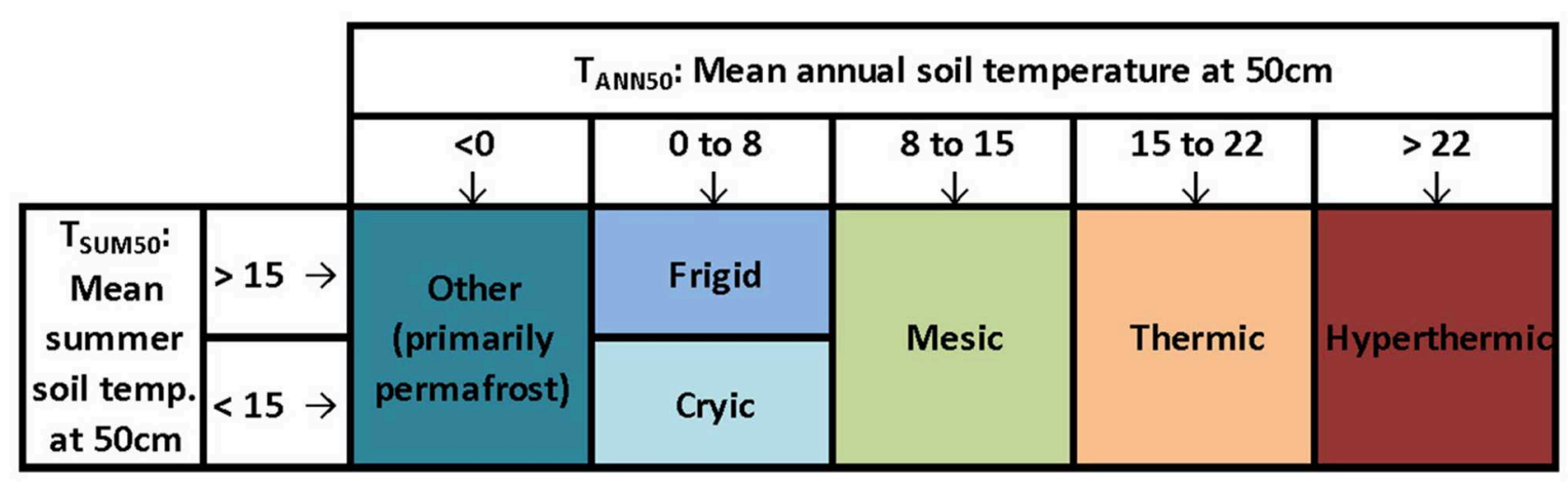

FIGURE 1 | Simplified relationships between soil temperature regimes (colors) and primary criteria for distinguishing the regimes. See text for descriptions of criteria. 


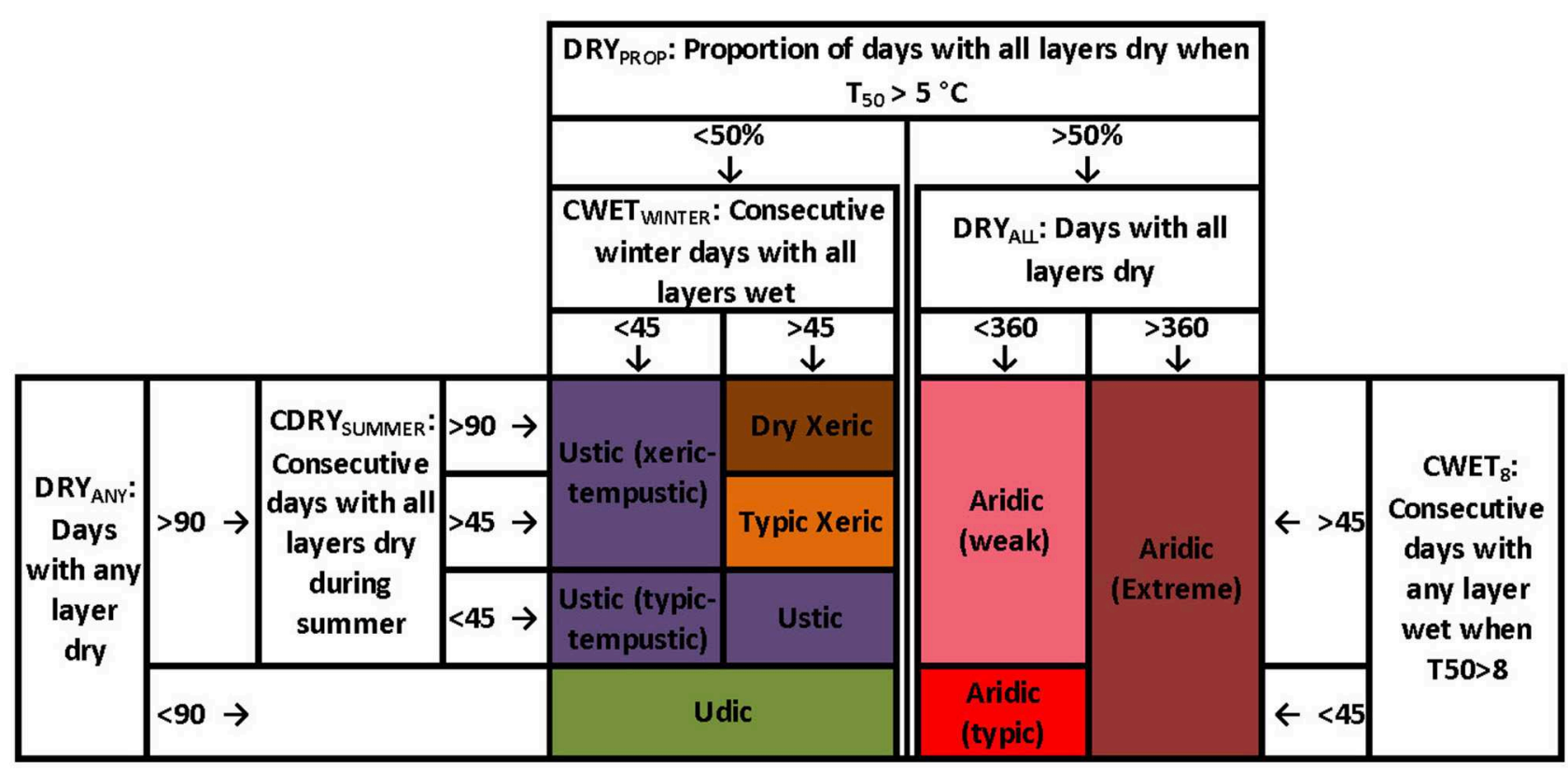

FIGURE 2 | Simplified relationships among soil moisture regimes (colors) and primary criteria for distinguishing the regimes. See text for descriptions of criteria.

exception of Frigid and Cryic, which are further distinguished from one another by $\mathrm{T}_{\text {SUM50 }}$ : soils with $\mathrm{T}_{\text {SUM } 50}>15^{\circ} \mathrm{C}$ are characterized as Frigid, while Cryic regimes are defined by $\mathrm{T}_{\text {SUM50 }}<15^{\circ} \mathrm{C}$.

Soil moisture regimes are defined (Soil Survey Staff, 2014) by combinations of several variables (Figure 2) describing the frequency and seasonality of wet $(>-1.5 \mathrm{MPa})$ soil conditions within the moisture control section (MCS: soil layers with depth ranging from 10 to $30 \mathrm{~cm}$ for fine textures to $30-90 \mathrm{~cm}$ for coarse textures; Soil Survey Staff, 2014). We focus here on the three most important variables for differentiating among the moisture regimes in drylands of western North America: DRY CWET $_{\text {WINTER, and CDRY }}$ SUMMER. First, the proportion of days that all layers within the MCS are dry when soil temperature

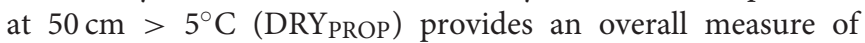
aridity and distinguishes Aridic from all other regimes. The other two variables represent seasonal patterns of moisture availability in non-aridic areas, and distinguish between Ustic (seasonally summer moist) and Xeric (seasonally winter moist) conditions. These are the number of consecutive days with all MCS layers wet during the winter (CWETWINTER: winter here defined as the 4 months following the winter solstice), and the number of consecutive days with all MCS layers dry during the summer (CDRY SUMMER: summer defined as the 4 months following the summer solstice). In the Supplementary Materials, we also provide results for three other soil moisture variables that relate to the soil moisture regimes but are not as influential for the western U.S: DRY ALL, $\mathrm{CWET}_{8}$, and DRY ANY (Figure 2). Two variables distinguish among Aridic-weak, Aridic-typic, and Aridic-extreme regimes: the number of days with all MCS layers dry $\left(D R Y_{A L L}\right)$, and the number of consecutive days with any layer wet when soil temperature at $50 \mathrm{~cm}$ depth $\left(\mathrm{T}_{50}\right)$ is $>8^{\circ} \mathrm{C}$
$\left(\mathrm{CWET}_{8}\right)$. The last variable, the number of days when any soil layer in the MCS is dry (DRY $\left.\mathrm{DNY}_{\mathrm{A}}\right)$, differentiates wetter Udic conditions from Xeric and Ustic conditions.

\section{Ecohydrological Modeling}

Current and future patterns of soil temperature and moisture were assessed using the SOILWAT2 ecosystem water balance model (Schlaepfer and Andrews, 2018; Schlaepfer and Murphy, 2018). SOILWAT2 (described in Appendix 5) is a daily time step, multiple soil layer, process-based, simulation model of ecosystem water balance that has been applied in numerous dryland ecosystems (Bradford and Lauenroth, 2006; Lauenroth and Bradford, 2006; Schlaepfer et al., 2012, 2017; Bradford et al., 2014a,b; Tietjen et al., 2017). Inputs to SOILWAT2 include daily temperature and precipitation, mean monthly relative humidity, wind speed and cloud cover, monthly vegetation (live and dead biomass, litter, and active root profile) and site-specific properties of each soil layer. For each $10 \mathrm{~km}$ cell, we estimated soil temperature and moisture conditions for four different soil types. We simulated conditions using site-specific soils (Figure S4.1), based on data for each soil layer (sand \%, clay \%, volume of gravel, bulk density, soil depth) for each grid cell from the aggregated databases NRCS STATSGO (1 km2 grids; Miller and White, 1998) within the United States and ISRIC-WISE v1.2 (5arcmin; Batjes, 2012) for areas in Canada. Results from these site-specific simulations are the primary focus of the manuscript. However, to provide insight into the influence of divergent soil conditions, we also simulated conditions in three fixed soil types that included a clay loam (27\% sand, 35\% clay, 38\% silt), a sandy loam (66\% sand, $9 \%$ clay, $25 \%$ silt), and a silt loam (16\% sand, $9 \%$ clay, $75 \%$ silt). Results from these fixed soil simulations are presented in Appendix 3. For each cell, we estimated the 
relative composition of $\mathrm{C}_{3}$ and $\mathrm{C}_{4}$ grasses and woody plants as well as monthly biomass, litter, and root depth distributions from climate conditions (e.g., relatively more C4 grasses in warm areas with high summer precipitation, more $\mathrm{C} 3$ grasses in cooler areas with winter precipitation, and more shrubs in cool-dry areas with winter precipitation; Paruelo and Lauenroth, 1996) using methods described in Bradford et al. (2014b) and Palmquist et al. (2016a).

\section{Climate Scenarios and Data Sources}

Climate data layers included both current and future climatic conditions developed for a $10-\mathrm{km}$ resolution grid across western North America. We used NCEP/CFSR products (Saha et al., 2010) for current climate conditions (1980-2010) by extracting daily maximum and minimum temperature ( $2 \mathrm{~m}$ above ground) and precipitation from the 6-hourly T382 products (U. S. National Centers for Environmental Prediction, 2010a,b). For future conditions, we extracted climate conditions as monthly time-series for two time periods, 2020-2050 and 2069-2099, from 1/2-degree downscaled and bias-corrected products of the fifth phase of the Climate Model Intercomparison Project (Taylor et al., 2012) (CMIP5). We extracted data from all available general circulation models (GCMs) for two representative concentration pathways (RCP4.5-37 GCMs; RCP8.5-35 GCMs) (Moss et al., 2010). We obtained data from the "Downscaled CMIP3 and CMIP5 Climate and Hydrology Projections" archive (Maurer et al., 2007) at http://gdo-dcp.ucllnl.org/downscaled_cmip_ projections/. We combined historical daily data (NCEP/NFSR) with monthly GCM predictions of historical and future conditions with a hybrid-delta downscaling approach to obtain future daily forcing (Hamlet et al., 2010; Tohver et al., 2014).

\section{Soil Regimes and Resilience/Resistance Categorization}

The National Cooperative Soil Survey has developed an algorithm, described in Soil Survey Staff (2014). We implemented the soil temperature and moisture regime logic in conjunction with the SOILWAT2 model, as described in the vignette "SoilMoistureRegimes_SoilTemperatureRegimes" of the R package rSOILWAT2 (Schlaepfer and Murphy, 2018). The basic criteria used to determine soil temperature and moisture regimes are illustrated in Figures 1, 2, respectively. We evaluated conditions during "normal" years, which are defined as having annual temperature, annual precipitation, and monthly precipitation for at least 8 of the 12 months within one standard deviation of long-term mean conditions (Soil Survey Staff, 2014). For each grid cell, we examined the specific soil temperature and moisture variables described above during normal years to determine the appropriate soil temperature and moisture regime, based on the criteria summarized in Figures 1, 2. Logic for assigning resilience and resistance classes based on soil temperature and moisture regimes have been developed for various regions (Chambers et al., 2014c, 2016; Maestas et al., 2016). We synthesized these categorizations (Figure S2.4) and applied them to assign current and potential future ecosystem resilience and resistance. We only evaluated resilience and resistance in big sagebrush dominated ecosystems, which is where assessments of the R \& R categories have been developed. These systems are defined here as the extent of the greater sagegrouse management zones (Figure S2.1), which are important conservation planning units in western North America (Manier et al., 2013).

\section{Ensemble Approach}

We calculated all variables and resulting regimes under historical climate conditions and for each GCM under both RCPs and for both time periods. We present results for the median GCM within each RCP and time period, and identify areas where $>90 \%$ of the GCMs within each RCP and time period (i.e., $>33$ GCMs under RCP4.5 and >31 under RCP8.5) agree on either the direction of change in continuous temperature or moisture variables, or agree on the regime categorization. All analyses on simulation output variables were performed in $\mathrm{R}$ version 3.3.2 ( $\mathrm{R}$ Core Team, 2016).

\section{RESULTS}

Averaged across our entire study region, the median climate model indicated near-term (2020-2050) mean annual air temperature increases of $\sim 1.7^{\circ} \mathrm{C}$ under RCP8.5 (ranges described here represent $10-90 \%$ of GCMs, which in this case was $1.2-$ $\left.2.4^{\circ} \mathrm{C}\right)$ and $1.5^{\circ} \mathrm{C}$ under RCP4.5 $\left(0.9-2.0^{\circ} \mathrm{C}\right)$. In the long-term (2070-2100), temperature increases grow to $4.9^{\circ} \mathrm{C}$ for RCP8.5 $\left(3.5-6.4^{\circ} \mathrm{C}\right)$ and $2.6^{\circ} \mathrm{C}$ for RCP4.5 $\left(1.6-3.7^{\circ} \mathrm{C}\right)$. For both the nearterm and long-term projections, areas where more than $90 \%$ of the GCMs indicated temperature increases were ubiquitous, and the magnitude of the increase in temperature was reasonably consistent across these North American drylands (Figure S1.1). By contrast, projections for changes in annual precipitation varied substantially both geographically and among GCMs (Figure S1.2). Under RCP8.5, average near-term precipitation change across the study region for the median GCM is $+15 \mathrm{~mm}$ with $10-90 \%$ of GCMs ranging from of $-23 \mathrm{~mm}$ to $+56 \mathrm{~mm}$. In the long-term, average precipitation change for the median $\mathrm{GCM}$ was $+22 \mathrm{~mm}(-36 \mathrm{~mm}$ to $+89 \mathrm{~mm})$. Locations where $>90 \%$ of GCMs agree in the direction of change in mean annual precipitation included only areas with projected precipitation increases and were confined in the near term to small areas in Wyoming and the northwest portion of the study area (Figure S1.2). In the long term, areas with robust projections for increasing precipitation are more widespread but still confined to the northern portion of North American drylands.

\section{Soil Temperature}

Averaged across the study area, mean annual soil temperature at $50 \mathrm{~cm}$ depth $\left(\mathrm{T}_{\mathrm{ANN} 50}\right)$ increased for all future climate scenarios (Figure 3 and Figure S1.4). $\mathrm{T}_{\mathrm{ANN} 50}$ increase in the near-term (2020-2050) averaged $1.25^{\circ} \mathrm{C}$ for the median GCM under RCP8.5 (10-90\% of GCMs: $\left.0.7^{\circ}-1.9^{\circ} \mathrm{C}\right)$ and $1.1^{\circ} \mathrm{C}$ under RCP4.5 $\left(0.4-1.7^{\circ} \mathrm{C}\right)$. For the long-term (2070-2100), average $\mathrm{T}_{\text {ANN50 }}$ was projected to increase to $3.6^{\circ} \mathrm{C}$ for the RCP8.5 median GCM $\left(2.3^{\circ}-5.0^{\circ} \mathrm{C}\right)$, and $1.9^{\circ} \mathrm{C}$ under RCP4.5 (GCM range $0.9^{\circ}-3.0^{\circ} \mathrm{C}$, Figure $\left.\mathbf{S 1 . 4}\right)$. Summer soil temperature at $50 \mathrm{~cm}$ depth $\left(\mathrm{T}_{\text {SUM50 }}\right)$ increased under all future scenarios 

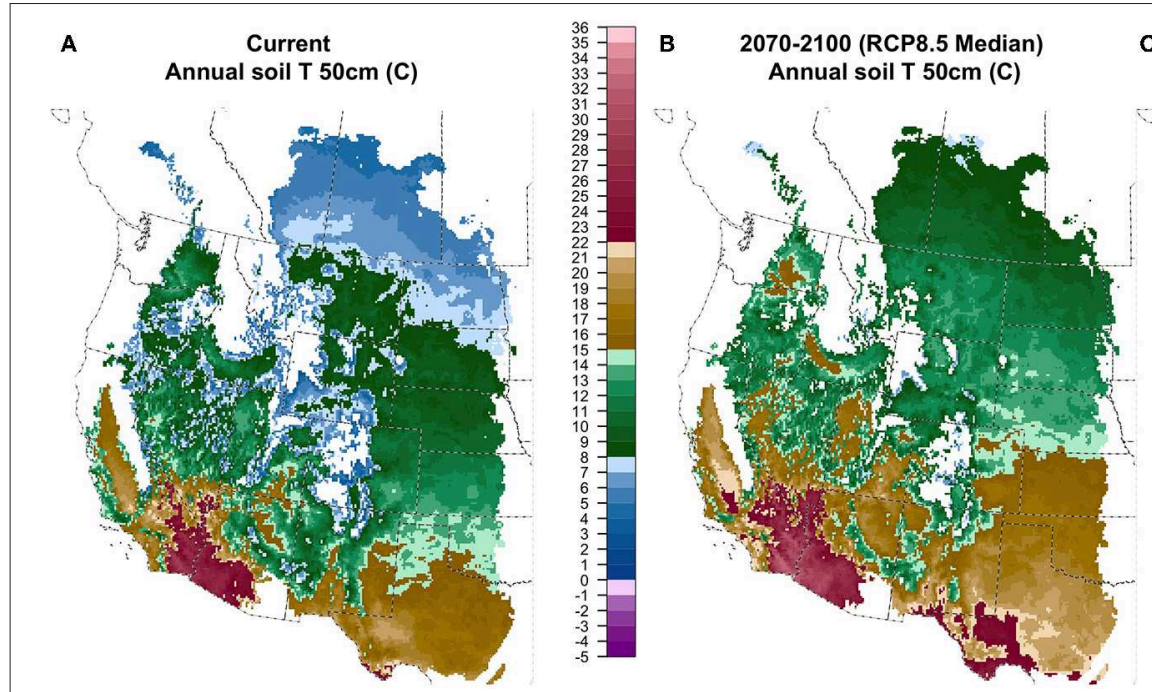
C Change in Annual soil T $50 \mathrm{~cm}$ (C)
(RCP8.5 median)

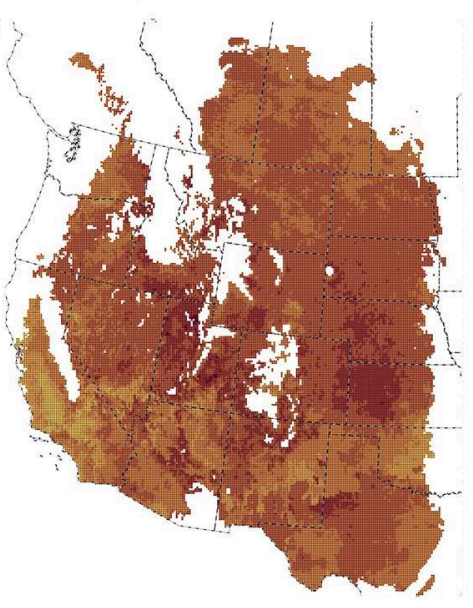

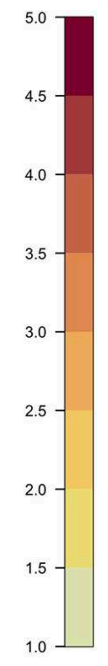

FIGURE 3 | Current (A), future (B; 2070-2100; RCP8.5 median model), and change (C) in T50ANN: mean annual soil temperature ( $\left.{ }^{\circ} \mathrm{C}\right)$ at $50 \mathrm{~cm}$ depth.
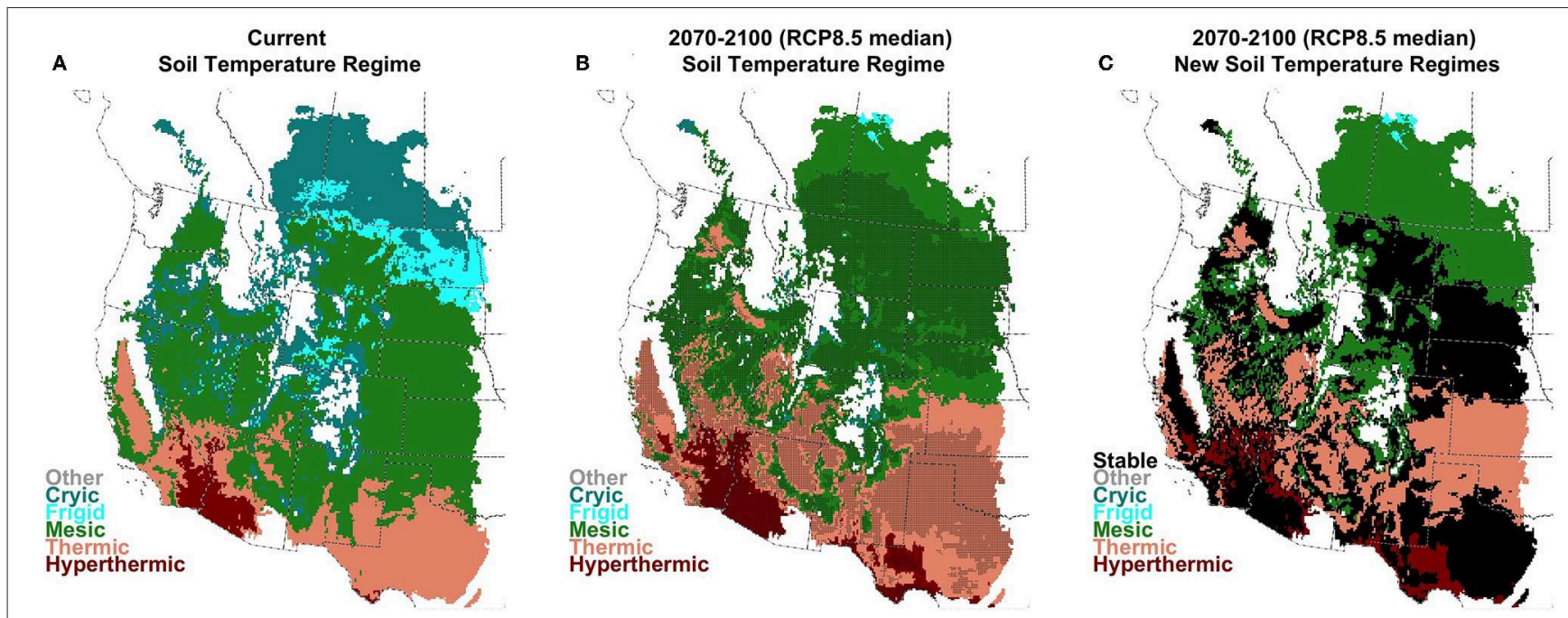

FIGURE 4 | Current (A), future (B; 2070-2100; RCP8.5 median model), and change (C) in soil temperature regimes. Stippling indicates areas where > 90\% of climate models agree on the assignment of the regime under future conditions.

(Figure S1.5), with slightly larger magnitudes and stronger geographic patterns than $\mathrm{T}_{\mathrm{ANN}}$ 50. These temperature increases supported substantial shifts in the geographic distribution of soil temperature regimes (Figure 4 and Figure S1.6). The extent of cooler Cryic and Frigid regimes, currently representing 31\% of the region, were projected to represent only $19 \%$ in the nearterm for RCP8.5 (21\% for RCP4.5), and $<2 \%$ in the long-term for RCP8.5 (14\% for RCP4.5). Thermic and Hyperthermic regimes, currently found only in the southern portion of the region, expanded from $21 \%$ of the region to $28 \%$ in the near-term for RCP8.5 (27\% for RCP 4.5) and 41\% in the long-term (32\% for RCP4.5). Mesic soil temperatures increased modestly, from $48 \%$ of the region currently to $53 \%$ in the near-term (52\% for RCP4.5) and 58\% in the long-term (54\% for RCP4.5). Especially for RCP8.5 and the long-term, Thermic and Hyperthermic regimes expanded in the southern and middle portion of the study area, at the expense of the Mesic regime, which shifted northward.

\section{Soil Moisture Overall Aridity}

Aridic soil moisture regimes are distinguished from other regimes by DRY $\mathrm{PROP}>50 \%$, where $\mathrm{DRY}_{\mathrm{PROP}}$ is the proportion of warm days $\left(\mathrm{T}_{50}>5\right)$ that have entirely dry soils (warm and dry days divided by total warm days; Figure 2). For the median GCM, we found that future climate conditions promoted increases on average in both the number of warm days (Figure S1.7) and the number of warm and dry days (Figure S1.8). Near-term projections for the median GCM suggest an increase of 16 warm days for RCP8.5 (10-90\% of GCMs: 9-26 days) and 14 days for RCP4.5 (6-22 days). Long-term projections indicated 45 more 

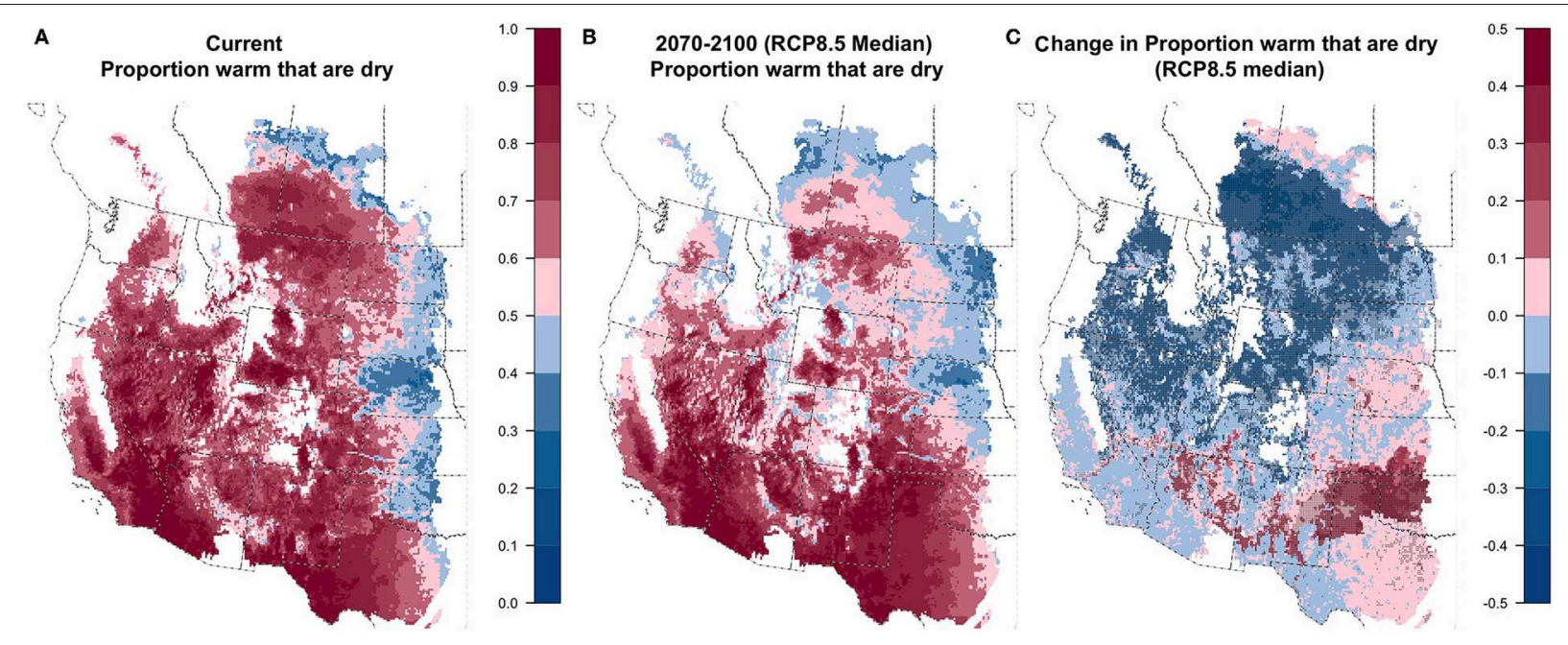

FIGURE 5 | Current (A), future (B; 2070-2100; RCP8.5 median model), and change (C) in DRY PROP: proportion of days with all soil layers dry when $\mathrm{T}_{50}>5^{\circ} \mathrm{C}$.

warm soil days per year for the median GCM for RCP8.5 (30-61 days) and 25 more days for RCP4.5 (12-39 days). Projections for increases in days that are both warm and dry generally increased slightly slower than warm days. Projected increases in warm-dry days for the median GCM are only 6 (10-90\% of GCMs: -9 to 21) for both RCP8.5 and RCP4.5, while long-term increases are 20 days for RCP8.5 ( -2 to 47 days) and 11 days for RCP4.5 ( -7 to 30 days). In most parts of these drylands, particularly the central and northern portions of the region, the projected increase in warm days exceeded the increase in warm and dry days (Figure S4.2), resulting in lower DRY ${ }_{\mathrm{PROP}}$ (Figure 5 and Figure S1.9). In other limited portions of the region, notably the central and southern Great Plains and portions of the ArizonaNew Mexico highlands, DRY PROP was projected to increase in the future as the number of warm and dry days outpaces the number of warm days. For locations meeting the overall criteria to be considered aridic ( $\mathrm{DRY}_{\mathrm{PROP}}>50 \%$ ), weak aridic is characterized by having $>45$ consecutive hot days $\left(T_{50}>8\right)$ with any soil layer wet, a condition that increased in prevalence across most of the region (Figure S1.10) probably because the number of hot days was greater in the future. Extreme aridic regimes are distinguished by having $>360$ days with all soil layers dry. Although the number of days with all dry soils increased across some portions of the region (Figure S1.11), very few areas had more than 360 entirely dry days under either current or future conditions.

\section{Soil Moisture Seasonality}

Very little of the study region has $<90$ days with any soil layer dry, which is necessary to qualify as the relatively wet Udic soil moisture regime (Figure S1.12). As a result, moisture patterns in the non-arid areas are defined (Figure 2) by either winter soil moisture availability (Xeric) or summer soil moisture availability (Ustic). Winter moisture is quantified by CWET ${ }_{\text {WINTER, }}$, the number of consecutive winter days with all soil layers wet. Projections for CWET WINTER indicated increasing winter moisture over most of the northwest and north-central portions of our region and decreases in much of the southeastern area, with broad areas where $90 \%$ of GCMs agreed on the direction of change (Figure 6 and Figure S1.13). Summer moisture availability is quantified by the number of consecutive summer days when all soil layers are dry (CDRY SUMMER , which was projected to change only modestly with both increases and decreases expected (Figure 7 and Figure S1.14). The exception was the eastern portion of our study area, covering much of the central Great Plains, where CDRY SUMMER was projected to increase in $>90 \%$ of GCMs and median increases were $>20$ days over large areas, particularly for RCP8.5.

Climate-driven changes in the metrics related to aridic soil moisture regimes, and to the seasonality of soil moisture availability for wetter locations combined to alter the geographic patterns of soil moisture regimes within drylands of western North America. However, the changes differed substantially among regions (Figure 8 and Figure S1.15). Throughout much of the northern portion of these drylands, decreasing proportion of warm days that have dry soils (as quantified by DRY ${ }_{\text {PROP }}$ ) resulted in less area with an aridic soil moisture regime. Aridic soil moisture regimes are currently found across $43 \%$ of this region, and that proportion is projected to decrease in the near-term to $34 \%$ under RCP8.5 (GCM range: $23-$ $52 \%)$ and $36 \%$ for RCP 4.5 (24-53\%). In the long term, aridic regimes decrease to $30 \%$ for RCP8.5 (19-47\%) and 33\% for RCP4.5 (21-50\%). In the intermountain portions of these areas, characterized by the Greater Sage-grouse Management Zones (Figure S2.3), areas with aridic regimes were replaced with xeric regime classifications, with the exception of the northern Great Plains where aridic-classified areas were replaced with ustic soil moisture classifications. Changes in the southern portions of these drylands were more variable, although increasing aridity was projected in northeast New Mexico and the Texas and Oklahoma panhandles (Figure 8). 

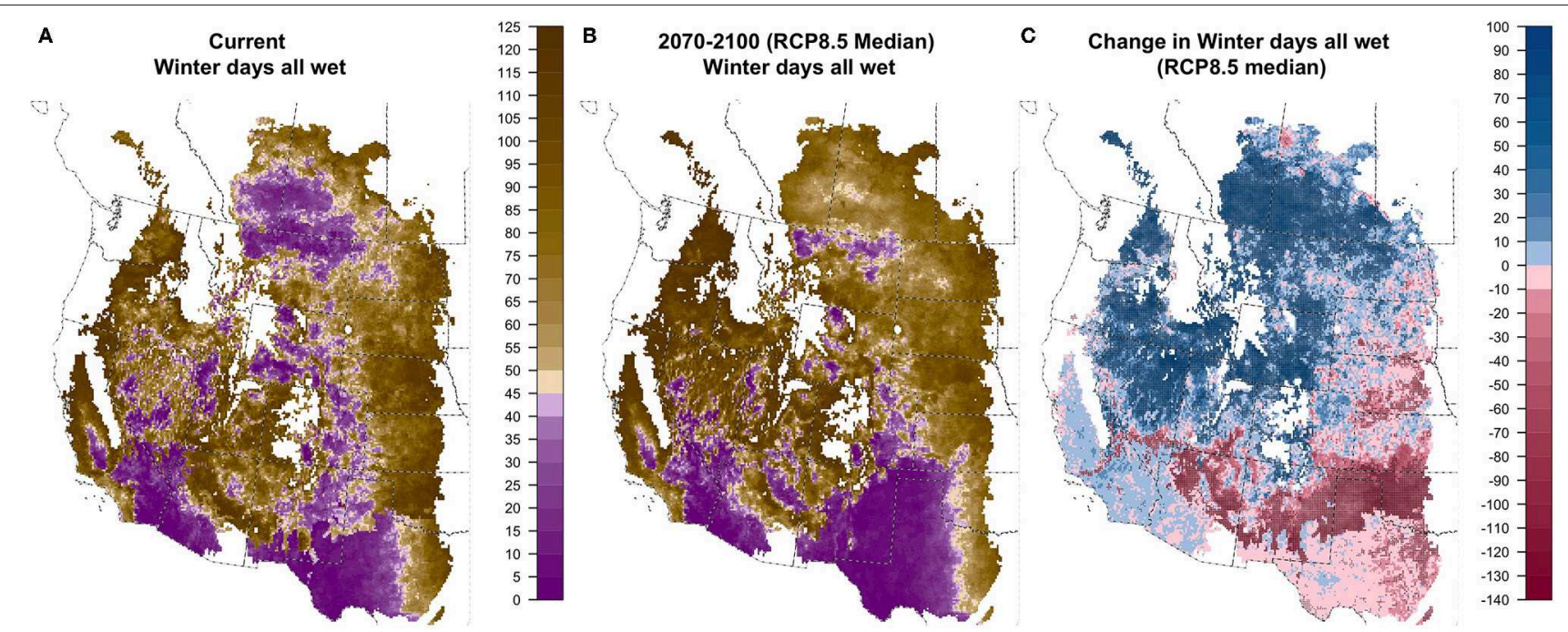

FIGURE 6 | Current (A), future (B; 2070-2100; RCP8.5 median model), and change (C) in CWET WINTER: consecutive winter days with all soil layers wet.
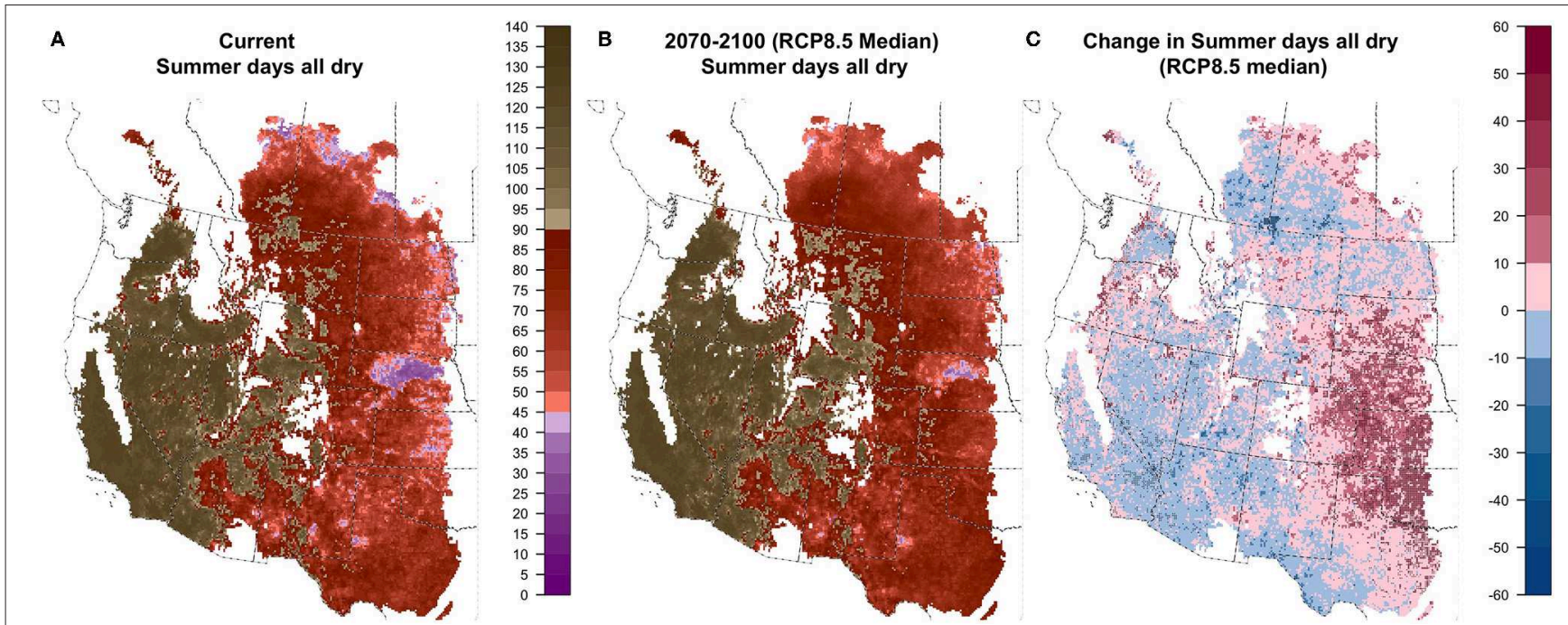

FIGURE 7 | Current (A), future (B; 2070-2100; RCP8.5 median model), and change (C) in CDRY SUMMER: consecutive summer days with all layers dry.

\section{Resilience and Resistance in Big Sagebrush Dominated Areas}

With only very minor regional variation, high $R \& R$ are linked to cold and wet conditions, while low R\&R are linked to hot and dry conditions (Figure S2.4). Our results examining the effect of climate change on soil temperature and moisture regimes implies decreasing abundance of both low and high $R \& R$, and an associated increase in moderate $R \& R$, especially in the long-term for RCP8.5 (Figures S2.5, S2.6). Rising soil temperatures create few areas with Cryic and Frigid temperature regimes (Figure S2.2), and thereby reduce the extent of areas categorized as high R\&R from $42 \%$ of the region under current conditions to $23 \%$ in the long-term under RCP 8.5 (37\% under RCP4.5; Figures 9, 10, and Figures S2.5, S2.6). Many of these areas become moderate-low $R \& R$, which increases from $2 \%$ of the region currently to $21 \%$ in the long-term under RCP 8.5 (11\% under RCP 4.5). Simultaneously, as fewer locations meet the criteria defined for the aridic soil moisture regime (described above), areas categorized as low $\mathrm{R} \& \mathrm{R}$ decrease from $16 \%$ currently to $3 \%$ in the long term under RCP 8.5 ( $8 \%$ under $\mathrm{RCP} 4.5)$. Moderate $\mathrm{R} \& \mathrm{R}$ areas increase from $38 \%$ currently to $53 \%$ in the long-term under RCP8.5 (44\% under RCP4.5; Figure 9 and Figures S2.5, S2.6).

\section{Variability Among Soil Types}

Results for the three fixed soil types that we examined in addition to the site-specific soils indicated that soil temperature conditions are relatively unimpacted by soil texture, while soil 

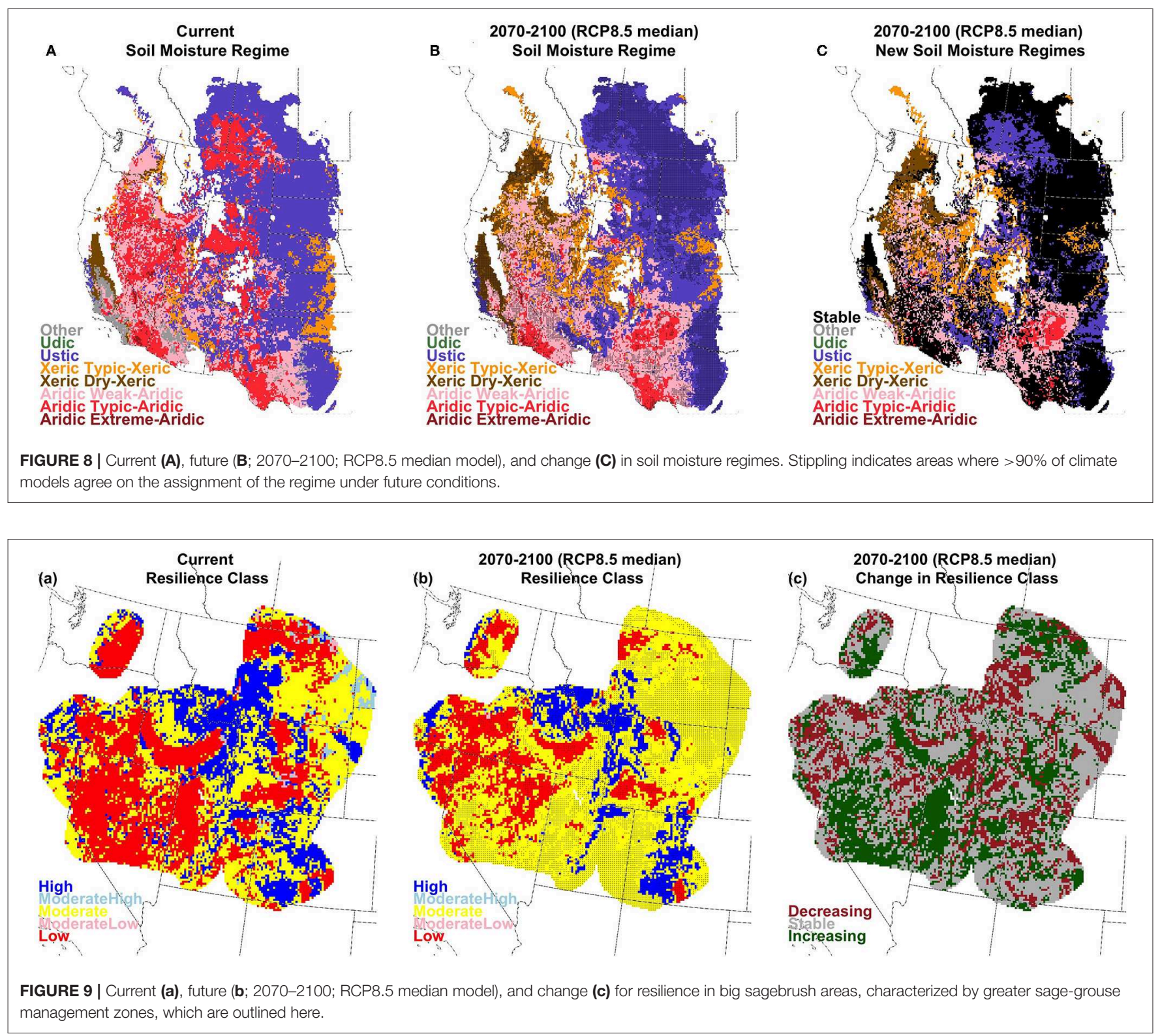

moisture displays important variability in response to texture. Projected future increases in soil temperature, and resulting consequences for the distribution of soil temperature regimes, were very consistent across soil types (Figures S3.1, S3.2). Sandy loam soils had lower DRY $\mathrm{PROP}$ than either the clay loam or silt loam soils, and generally lower than the sitespecific soils (except where local soil texture is extremely coarse; Figure S3.3). Sandy loam soils also generally displayed

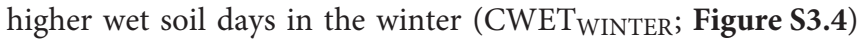
and slightly lower dry days in the summer CDRY SUMMER; Figure S3.5) than the other textures. These differences mean that, compared to silt-loam or clay-loam soils, sandy loam soils support slightly less area with aridic soil moisture conditions and slightly greater area with ustic and xeric conditions although these differences decrease under future climate conditions when aridic soil moisture regimes are less common for all soil textures (Figure S3.6). Although the regional abundance of R\&R categories are relatively similar among the soil types, the detailed geographic patterns of these categories do vary by soil type (Figures S3.7, S3.8).

\section{DISCUSSION}

Quantitative evaluation of climate vulnerability and ecological resilience to global change at broad spatial scales requires widely available information about relevant environmental conditions that influence how ecosystems respond to stressors like drought, invasive species, and disturbance (Chambers et al., 2019a). In dryland regions, soil temperature and moisture regimes are widely utilized as foundational 

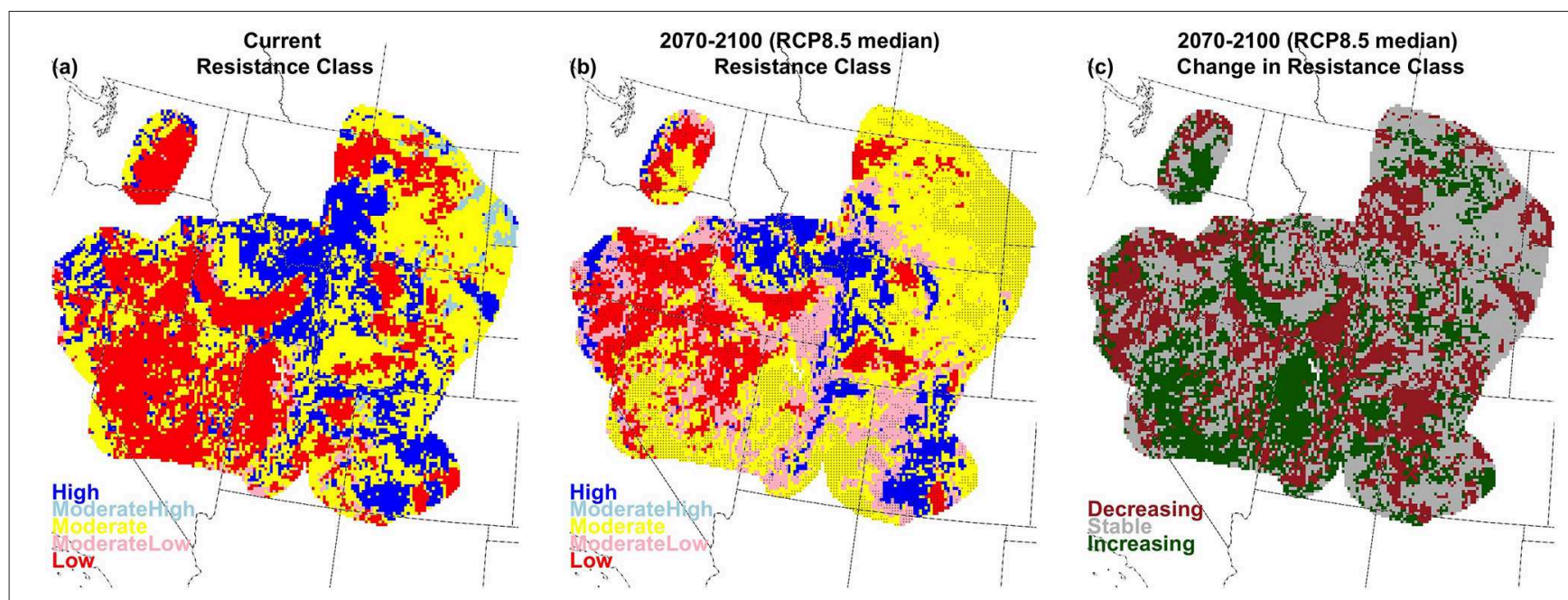

FIGURE 10 | Current (a), future (b; 2070-2100; RCP8.5 median model), and change (c) for resistance in big sagebrush areas, characterized by greater sage-grouse management zones, which are outlined here.

indicators of resilience to disturbances, such as wildfire, and resistance to invasive plants, such as non-native annual grasses (Chambers et al., 2019b). By estimating how longterm climate trajectories will alter these regimes, our results provide insight into potential refinements that may help existing landscape-scale assessments of resilience and resistance better capture dryland ecological dynamics in a shifting climate.

\section{Consistent Temperature Increases}

Projections for substantial soil temperature increases in the twenty-first century are the most unambiguous and geographically consistent result from this analysis. Soil temperatures increase between historical and the 20202050 timeframe, and continue to increase substantially by 2070-2100, exemplifying the long-term divergence between historical and future climate conditions. More than $90 \%$ of the climate models concurred that air temperature and annual soil temperature will rise across the entire dryland domain and these increases are very consistent among soil types. Nearly the entire domain displayed similar consistent projections for increasing summer soil temperature. Soil temperatures are influenced by long-term effects of both air temperature and precipitation patterns, and these increases underscore the magnitude of change in energy balance expected. Higher soil temperatures may influence ecosystem carbon fluxes by promoting higher respiration rates that result in overall decreased ecosystem carbon stocks (Davidson and Janssens, 2006). This net release of carbon may alter the global carbon cycle, potentially increasing atmospheric carbon dioxide concentrations and providing a positive feedback to ongoing global warming (Bond-Lamberty et al., 2018). In addition, these rising temperatures highlight the growing risk for hot droughts in these already water limited ecosystems (Overpeck, 2013).

\section{Geographic Variability in Moisture Projections}

While projections for increasing temperature display relative geographic consistency, our results suggest substantial geographic variation in anticipated changes to soil moisture conditions. The largest divergence is between the central and northwest portion of our study region, where soil moisture availability appears likely to increase, and the southeastern portion, where soil moisture is expected to decline. The northwestern areas of our study region include the intermountain zone in the United States and much of the northern Great Plains, including southern Alberta and Saskatchewan. For broad areas within this area, several variables indicate increasing moisture availability that are robust across climate models, including decreases in the proportion of warm days with dry soil (Figure S1.9), decreases in overall days with soils that are entirely or partially dry (Figures S1.11, S1.12, respectively), and increases in days with entirely wet soil in the winter (Figure S1.13)

Ecosystems historically dominated by big sagebrush (Artemisia tridentata) are a major component of the areas with projections for increasing moisture availability. In recent years, big sagebrush ecosystems have become an important focus for policy makers and natural resource managers because of the widespread changes in vegetation structure and plant species composition (Knick et al., 2011) that impact the value of these systems as crucial wildlife habitat (Connelly et al., 2000; Crawford et al., 2004). Many of the moisture variables indicate increases in soil moisture availability in the future across areas with plant communities dominated by big sagebrush, implying that they may be able to persist under a changing climate if the plant communities can adapt their phenology in response to hotter, drier summer conditions accompanied by wetter, warmer spring and fall seasons (Palmquist et al., 2016a; Renwick et al., 2017). In particular, within regions established to 
guide the management of the big sagebrush-dependent greater sage grouse (Centrocercus urophasianus), the abundance of aridic soil moisture regimes are expected to decline while the abundance of xeric regimes increase. It is important to note that the declining abundance of areas with aridic soil moisture regime within the big sagebrush region is driven by a decline in the proportion of warm soil days that also have dry soils (which is the criteria used to determine if a site qualifies for the aridic moisture regime designation). This metric of aridity may not be an optimal measure of the severity of ecological drought, as illustrated by the fact that most sites within the big sagebrush region are also expected to display increases in the number of hot days, and increases in the number of hot and dry days. In addition, the projections for modest increases in soil moisture in big sagebrush ecosystems by no means indicates that those systems are not imperiled by global change; interactions among wildfire and invasive annual grasses are major contributors driving historical big sagebrush decline (West, 2000; Knick et al., 2011; Balch et al., 2013), and loss of big sagebrush in response to these fire-invasive dynamics may continue in spite of stable or increasing moisture availability.

In contrast to the northwest and north-central regions, the southeastern and south-central portion of our study region displays uniform projections of declining moisture availability. These areas include the central and southern Great Plains and most of northern Arizona and New Mexico. Indicators of declining soil moisture availability that are robust across climate models for at least some of these areas include an increasing proportion of warm days that have dry soil (Figure S1.9), increasing dry soil days (Figures S1.11, S1.12), decreasing days with wet soil in the winter, and, for the central and southern Great Plains, decreasing days with wet soil in the summer (Figure S1.14). Previous studies have identified both the southwest and the central/southern Great Plains as areas with expected increases in aridity in the twenty-first century (Cayan et al., 2010; Seager and Vecchi, 2010; Cook et al., 2015), and our results about long-term declines in soil moisture underscore the potential consequences of this high exposure to climate change for resilience and resistance of these dryland ecosystems and the services that they provide (Bradford et al., 2017).

In addition to these broad regional patterns, the differences among soil types in soil moisture conditions, and future trajectories, suggest that edaphic conditions may play an increasingly important role in determining patterns of soil moisture. In particular, the sandy loam soils supported more favorable conditions for many of the soil moisture metrics, including lower proportion of warm days with dry soils (Figure S3.3b), more wet days in the winter (Figure S3.4b), and less dry days in the summer (Figure S3.5b). Many of these soildriven differences are maintained or enhanced under future climate conditions.

\section{Implications for Assessing Resilience and Resistance}

The application of soil temperature and moisture regimes to define categories of ecological resilience to disturbance and resistance to invasive annual grasses has been most developed for big sagebrush ecosystems (Chambers et al., 2014b,c, 2019a,b; Williams and Friggens, 2017) where the framework has been used to prioritize conservation investments and land management strategies (Chambers et al., 2017a, 2019b; Crist et al., 2019). The approach used to define the current resilience and resistance categories involved identifying the dominant ecological types that currently exist in the sagebrush biome, determining their estimated soil temperature and moisture regimes based on mapped products from the National Cooperative Soil Survey, and then assigning resilience and resistance categories based on the available literature and expert knowledge (Chambers et al., 2014a, 2016, 2017b; Maestas et al., 2016). Our projections for the future of those regimes indicate two important considerations for long-term application of the framework using soil temperature and moisture regimes as the indicator of resilience and resistance.

First, the substantial increases in soil temperature, and the resulting expectations for shifting soil temperature regimes, imply geographic shifts in sagebrush ecological types and in ecological resilience and resistance categories across the landscape. Big sagebrush plant communities typically do not exist in areas with thermic soil temperature regimes and our results indicate that thermic soil temperature conditions will become more prevalent in the future, including in some areas currently occupied by big sagebrush. Because resilience to disturbance is assumed to decline with each transition to a warmer soil temperature regime (e.g., from cryic to frigid to mesic; Chambers et al., 2014c, 2016; Maestas et al., 2016), these rising temperatures, and associated shifts in soil temperature regimes in big sagebrush ecosystems may have dramatic impacts on future resilience and resistance of big sagebrush ecosystems. Specifically, changing from mesic to thermic soil temperature conditions may represent a shift from conditions that support big sagebrush plant communities to conditions that would be expected to support warmer and drier Cold Desert plant communities or even Mojave Desert plant communities in some areas (Rehfeldt et al., 2012). Also, these shifts may mean that these areas no longer have the climatic potential to support the dominant non-native invader, cheatgrass (B. tectorum), and that it may be replaced by red brome (B. rubens) or other non-native invasive plant species (Bradley et al., 2016).

Second, applying the expected shifts in soil temperature and moisture conditions using the current framework will estimate an increasing proportion of the big sagebrush region as intermediate R\&R categories (Appendix 2). Currently, high or moderately high resilience or resistance in big sagebrush ecosystems is primarily associated with cryic or frigid temperature regimes (Chambers et al., 2014a,b, 2017b, 2019a), conditions projected to decrease in the future. In contrast, aridic soil moisture conditions are typically associated with low resilience and resistance in big sagebrush ecosystems. In the future, fewer areas will satisfy the criteria for aridic soil moisture regimes because aridic conditions are defined by the proportion of warm soil days that are also dry, and in most big sagebrush areas, warm days are increasing faster than warm-dry days. Although more areas would be classified as having moderate resilience and resistance 
based on this criterion alone, the effects of this change on sagebrush ecosystems and their relative resilience and resistance are difficult to predict. Focused monitoring and research in sagebrush ecosystems can update understanding of relationships among climate, soil and vegetation, responses to stressors and disturbances, and vulnerability to climate and drought. Identifying and formalizing metrics of environmental conditions that represent ecologically meaningful variation can improve estimates of ecological resilience and resistance. Ecologically appropriate metrics can be based upon abiotic conditions like climate and soils, as well as biotic conditions assessed using monitoring data and emerging remote sensing technology (Jones et al., 2018).

Our results about the future distribution and abundance of areas categorized as having aridic soil moisture conditions highlight a limitation in utilizing the soil temperature and moisture regimes for assessing ecosystem resilience in the context of long-term directional change in climate conditions. In particular, relying on the proportion of warm days that also have dry soils to determine if a site has an aridic soil moisture regime suggests that the soil moisture regimes, as currently calculated, may struggle to represent the drought consequences of increases in both warm and dry days. As soil temperatures increase, the total number of warm days increases substantially, whereas the number of dry days often increases more slowly, reducing the proportion of warm days with dry soils. As a consequence, broad areas currently categorized as aridic soil moisture conditions will shift to other categories, despite the fact that many of them will have increases in the total number of days with dry soil (Appendix 2).

An important additional limitation of utilizing the current soil temperature and moisture regimes as indicators of ecological resilience and resistance is that the thresholds used to distinguish among the soil temperature and moisture regimes were not selected to represent ecologically meaningful thresholds, particularly for dryland environments. The regime definitions have been used for many decades, and our understanding of the environmental drivers of dryland vegetation dynamics has progressed substantially during that time (Vicente-Serrano et al., 2013). For big sagebrush ecosystems, which have been a major focus of previous resilience and resistance categorization frameworks, there are several recent studies identifying climatic and drought conditions that are important in shaping these systems (Coates et al., 2016; Palmquist et al., 2016b; Roundy et al., 2018).

One limitation to using soil temperature and moisture regimes as an indicator of resilience and resistance is that the regimes are defined by long-term conditions during "normal" years. These metrics can provide only limited insight into conditions during extreme events which have recognized impacts on ecosystems (Smith, 2011). Future refinements to R\&R categories could include metrics that relate directly to the estimated severity of episodic, extreme drought, or drought and heat-wave conditions. Extreme events influence a wide variety of ecological processes, especially in dryland regions where precipitation and moisture availability are both important and highly variable (Gutschick Vincent and BassiriRad, 2003; Smith, 2011). For example, severe drought events can cause dryland plant mortality and decrease productivity in surviving individuals during subsequent years (Bigler et al., 2007; Bradford and Bell, 2017). At the other extreme, unusual wet conditions can interact with soil and stand characteristics to contribute to dryland plant mortality (Renne et al., 2019) as well as facilitate regeneration of perennial plants (Shriver et al., 2018), a notoriously episodic process (Schlaepfer et al., 2014; Petrie et al., 2016). Because the frequency and severity of extreme events can influence an ecosystem's composition, structure and susceptibility to biological invaders (Bradley et al., 2010; Reichstein et al., 2013; Ummenhofer and Meehl, 2017), incorporating metrics that represent ecologically relevant extreme drought conditions may improve assessments of resistance to invasion. Recognizing the role of extreme events may become even more crucial as climate change continues in coming decades, because the importance of extremes in shaping ecosystems may increase as extreme events become more frequent and intense (Stocker et al., 2013; Zhang et al., 2013).

Despite these limitations, soil temperature and moisture regimes have provided a practical indicator for contemporary assessment of resilience and resistance of North America's largest dryland ecosystem. The current $R \& R$ framework uses the available soil temperature and moisture regimes to represent geographic variability in environmental conditions and estimates how those regimes influence resilience to transformation due to wildfire, and invasive plant species. The differences that we observed in patterns of $R \& R$ categories among soil types suggest the existence of important, within-grid cell, soilmediated variation in ecological resilience. This fine-grained variability may provide differential lagged responses to changing climate and/or climate refugia that may be important to resource managers. Our projections of future changes in the temperature and moisture variables that define these regimes indicate processes and areas with changes that are consistent among climate models, and suggest a focus for ecological monitoring that will increase our understanding of the changes in the resilience of these ecosystems in the twentyfirst century.

These results suggest opportunities to enhance our quantification of geographic gradients in ecologically-relevant environmental conditions, currently represented by soil temperature, and moisture regimes, to sustain their long-term value as indicators of ecological resilience and risk-based management. One potential enhancement would be to assess the geographic distribution of temperature and moisture regimes using continuous time series of soil temperature and moisture data, either from a comprehensive network of observations or from process-based models as done here. These data, utilized in combination with existing soil survey information and other field measurements, could provide a useful tool for enhancing existing products produced by the National Cooperative Soil Survey and ensuring consistency across space and time. These data would allow managers to better forecast soil temperature and moisture regimes at regional scales with changing climate conditions. In addition, as long-term climate trajectories unfold, the links between 
soil temperature and moisture conditions and ecological resilience and resistance need to be regularly re-evaluated to capture shifts in relationships between environmental conditions and ecological dynamics. Future assessments may include variables in addition to soil temperature and moisture regime classes that may be useful for understanding and representing important ecological thresholds in dryland ecosystems (Roundy et al., 2018).

\section{DATA AVAILABILITY STATEMENT}

The datasets generated for this study are available in Bradford and Schlaepfer (2019), at https://doi.org/10.5066/P9PJFE82.

\section{AUTHOR CONTRIBUTIONS}

JB with help from DS and WL, designed the research. DS with input from JB, completed the simulations. JB with help from DS and input from all authors, analyzed results. JB drafted the manuscript. All authors contributed to editing the manuscript.

\section{ACKNOWLEDGMENTS}

This work was supported by the USGS Ecosystems Mission Area. Any use of trade, product, or firm names is for descriptive purposes only and does not imply endorsement by the U.S. Government.

\section{SUPPLEMENTARY MATERIAL}

The Supplementary Material for this article can be found online at: https://www.frontiersin.org/articles/10.3389/fevo. 2019.00358/full\#supplementary-material

Appendix 1 | Detailed results for key variables. Layout for each variable includes maps under current conditions (top left), near-term and long-term under RCP 4.5 (top middle and top right, respectively) and RCP 8.5 (bottom middle and bottom right, respectively). Future maps illustrate the median climate model for each time period and RCP. Stippling in future maps indicates areas where $>90 \%$ of climate models agree in either the direction of change (continuous variables) or the assignment of regime (soil temperature and moisture regimes). Horizonal boxplots of each variable, and the change in each variable are depicted in the bottom left, for current and future conditions. Boxplots of future conditions include the climate model representing the $10 \%$, median (50\%) and $90 \%$ of all models examined for each time period and RCP. Variables presented include.

Figure S1.1 | Mean annual temperature (MAT).

Figure S1.2 | Mean annual precipitation (MAP).

Figure S1.3 | Ratio of mean annual precipitation to mean annual potential evapotranspiration (MAP/PET).

Figure S1.4 | Mean annual soil temperature at $50 \mathrm{~cm}$ depth $\left(T 50_{\mathrm{ANN}}\right)$.

Figure S1.5 | Mean summer soil temperature at $50 \mathrm{~cm}$ depth (T50 $\mathrm{SUM}$ ).

Figure S1.6 | Soil temperature regime.

Figure S1.7 | Mean annual days with soil temperature at $50 \mathrm{~cm}>5^{\circ} \mathrm{C}$ (DAYSWARM).

Figure S1.8 | Mean annual days with all soil layers dry in the moisture control section when soil temperature at $50 \mathrm{~cm}>5^{\circ} \mathrm{C}$ (DAYS WARMDRY $_{\text {). }}$
Figure $\mathbf{S 1 . 9}$ | Mean annual proportion of days when soil temperature at $50 \mathrm{~cm}>$ $5^{\circ} \mathrm{C}$ with all soil layers dry in the moisture control section (DRYPROP).

Figure S1.10 | Mean annual maximum consecutive days with wet soil when soil temperature at $50 \mathrm{~cm}>8^{\circ} \mathrm{C}\left(\mathrm{CWET}_{8}\right)$.

Figure S1.11 | Mean annual number of days with all soil layers dry in the moisture control section (DRY $\mathrm{ALL}_{\text {). }}$.

Figure S1.12 | Mean annual number of days with any soil layer dry in the moisture control section (DRY ANY).

Figure S1.13 | Mean annual number of consecutive days with all soil layers wet in the moisture control section during winter (CWET WINTER).

Figure S1.14 | Mean annual number of consecutive days with all soil layers dry in the moisture control section during summer (CDRY SUMMER $_{\text {). }}$.

Figure $\mathbf{S 1 . 1 5}$ | Soil moisture regime.

Appendix 2 | Results of regimes and resistance/resilience classification by sage-grouse management zone.

Figure S2.1 | Sage-grouse management zones. Zone 1: Great Plains; Zone 2: Wyoming Basins Zone 3: Southern Great Basin; Zone 4: Snake River Plain; Zone 5: Northern Great Basin; Zone 6: Columbia Basin; and Zone 7: Colorado Plateau.

Figure S2.2 | Projected proportions of each soil temperature regime for each greater sage grouse management zone.

Figure S2.3 | Projected proportions of each soil moisture regime for each greater sage grouse management zone.

Figure S2.4 | Lookup table for assigning resistance and resilience categories based on soil temperature and moisture, synthesized from previous studies.

Figure S2.5 | Layout for resistance within MZs.

Figure S2.6 | Layout for resilience within MZs.

Appendix 3 | Soil-specific results of key variables, soil temperature and moisture regimes, and resistance and resilience categories (for sage-grouse management zones). Results for continuous soil temperature and moisture metrics include current and future value for each variable under each soil type ("a" panels) and differences between site-specific soils (presented as the primary result in the manuscript) and each of the standard soil types. Results for categorical variables include only current and future estimates of the categories under each soil type and stippling indicates areas where $>90 \%$ of climate models agree in the category assignment.

Figure S3.1 | (a,b) Mean annual soil temperature at $50 \mathrm{~cm}$ depth $\left(\mathrm{T}_{50} \mathrm{ANN}_{\mathrm{AN}}\right)$.

Figure S3.2 | Soil temperature regime.

Figure S3.3 | (a,b) Mean annual proportion of days when soil temperature at $50 \mathrm{~cm}>5^{\circ} \mathrm{C}$ with all soil layers dry in the moisture control section (DRYPROP).

Figure S3.4 | (a,b) Mean annual number of consecutive days with all soil layers wet in the moisture control section during winter (CWETWINTER).

Figure $\mathbf{S 3 . 5}$ | (a,b) Mean annual number of consecutive days with all soil layers dry in the moisture control section during summer (CDRY SUMMER $_{\text {). }}$

Figure S3.6 | Soil moisture regime.

Figure S3.7 | Resistance class.

Figure S3.8 | Resilience class.

Appendix 4 | Other information.

Figure S4.1 | Site-specific soil texture and moisture control section depth.

Figure S4.2 | Projected change in warm \& dry days vs. projected change in warm days. Gray background points show all changes RCP 8.5, 2070-2100 vs. present. Colored isolines illustrate the distribution of changes for RCP4.5 2020-2050 vs. present (blue) and 2070-2100 vs. present (purple), and RCP8.5 2020-2050 vs. present (orange), and 2070-2100 vs. present (red).

Appendix 5 | Description of SOILWAT2. 


\section{REFERENCES}

Balch, J. K., Bradley, B. A., D’Antonio, C. M., and Gómez-Dans, J. (2013). Introduced annual grass increases regional fire activity across the arid western USA (1980-2009). Glob. Change Biol. 19, 173-183. doi: 10.1111/gcb.12046

Batjes, N. H. (2012). ISRIC-WISE Derived Soil Properties on a 5 by 5 arc-Minutes Global Grid (ver. 1.2). ISRIC-World Soil Information.

Bigler, C., Gavin, D. G., Gunning, C., and Veblen, T. T. (2007). Drought induces lagged tree mortality in a subalpine forest in the Rocky Mountains. Oikos 116, 1983-1994. doi: 10.1111/j.2007.0030-1299.16034.x

Bond-Lamberty, B., Bailey, V. L., Chen, M., Gough, C. M., and Vargas, R. (2018). Globally rising soil heterotrophic respiration over recent decades. Nature 560, 80-83. doi: 10.1038/s41586-018-0358-x

Bradford, J. B., and Bell, D. M. (2017). A window of opportunity for climatechange adaptation: easing tree mortality by reducing forest basal area. Front. Ecol. Environ. 15, 11-17. doi: 10.1002/fee.1445

Bradford, J. B., and Lauenroth, W. K. (2006). Controls over invasion of Bromus tectorum: the importance of climate, soil, disturbance and seed availability. J. Vegetation Sci. 17, 693-704. doi: 10.1111/j.1654-1103.2006.tb02493.x

Bradford, J. B., and Schlaepfer, D. R. (2019). Historical and 21st Century Soil Temperature and Moisture Data for Drylands of Western U.S. and Canada. U.S, Geological Survey Data Release. doi: 10.5066/P9PJFE82

Bradford, J. B., Schlaepfer, D. R., and Lauenroth, W. K. (2014a). Ecohydrology of adjacent sagebrush and lodgepole pine ecosystems: the consequences of climate change and disturbance. Ecosystems 17, 590-605. doi: 10.1007/s10021-013-9745-1

Bradford, J. B., Schlaepfer, D. R., Lauenroth, W. K., and Burke, I. C. (2014b). Shifts in plant functional types have time-dependent and regionally variable impacts on dryland ecosystem water balance. J. Ecol. 102, 1408-1418. doi: $10.1111 / 1365-2745.12289$

Bradford, J. B., Schlaepfer, D. R., Lauenroth, W. K., Yackulic, C. B., Duniway, M., Hall, S., et al. (2017). Future soil moisture and temperature extremes imply expanding suitability for rainfed agriculture in temperate drylands. Sci. Rep. 7:12923. doi: 10.1038/s41598-017-13165-x

Bradley, B. A., Blumenthal, D. M., Wilcove, D. S., and Ziska, L. H. (2010). Predicting plant invasions in an era of global change. Trends Ecol. Evol. 25, 310-318. doi: 10.1016/j.tree.2009.12.003

Bradley, B. A., Curtis, C. A., and Chambers, J. C. (2016). "Bromus Response to Climate and Projected Changes with Climate Change," in Exotic BromeGrasses in Arid and Semiarid Ecosystems of the Western US: Causes, Consequences, and Management Implications, eds M. J. Germino, J. C. Chambers, and C. S. Brown (Cham: Springer International Publishing), 257-274. doi: 10.1007/978-3-319-24930-8_9

Briske, D. D., Joyce, L. A., Polley, H. W., Brown, J. R., Wolter, K., Morgan, J. A., et al. (2015). Climate-change adaptation on rangelands: linking regional exposure with diverse adaptive capacity. Front. Ecol. Environ. 13, 249-256. doi: $10.1890 / 140266$

Cayan, D. R., Das, T., Pierce, D. W., Barnett, T. P., Tyree, M., and Gershunov, A. (2010). Future dryness in the southwest US and the hydrology of the early 21 st century drought. Proc. Natl. Acad. Sci. U.S.A. 107, 21271-21276. doi: 10.1073/pnas.0912391107

Chambers, J., Bradley, B., Brown, C., D’Antonio, C., Germino, M., Grace, J., et al. (2014a). Resilience to stress and disturbance, and resistance to Bromus tectorum L. invasion in cold desert shrublands of Western North America. Ecosystems 17, 360-375. doi: 10.1007/s10021-013-9725-5

Chambers, J. C., Allen, C. R., and Cushman, S. A. (2019a). Operationalizing ecological resilience concepts for managing species and ecosystems at risk. Front. Ecol. Evol. 7:241. doi: 10.3389/fevo.2019.00241

Chambers, J. C., Beck, J. L., Bradford, J. B., Bybee, J., Campbell, S., Carlson, J., et al. (2017a). Science Framework for Conservation and Restoration of the Sagebrush Biome: Linking the Department of the Interior's Integrated Rangeland Fire Management Strategy to Long-Term Strategic Conservation Actions, Part 1. Science Basis and Applications. Gen. Tech. Rep. RMRS-GTR-360. Fort Collins, CO. US Department of Agriculture, Forest Service).

Chambers, J. C., Beck, J. L., Campbell, S., Carlson, J., Christiansen, T. J., Clause, K. J., et al. (2016). Using Resilience and Resistance Concepts to Manage Threats to Sagebrush Ecosystems, Gunnison Sage-Grouse, and Greater Sage-Grouse in Their Eastern Range: A Strategic Multi-Scale Approach. U.S. Forest Service.
Chambers, J. C., Brooks, M. L., Germino, M. J., Maestas, J. D., Board, D. I., Jones, M. O., et al. (2019b). Operationalizing resilience and resistance concepts to address invasive grass-fire cycles. Front. Ecol. Evol. 7:185. doi: 10.3389/fevo.2019.00185

Chambers, J. C., Maestas, J. D., Pyke, D. A., Boyd, C. S., Pellant, M., and Wuenschel, A. (2017b). Using resilience and resistance concepts to manage persistent threats to sagebrush ecosystems and greater sage-grouse. Rangel. Ecol. Manage. 70, 149-164. doi: 10.1016/j.rama.2016.08.005

Chambers, J. C., Miller, R. F., Board, D. I., Pyke, D. A., Roundy, B. A., Grace, J. B., et al. (2014b). Resilience and resistance of sagebrush ecosystems: implications for state and transition models and management treatments. Rangeland Ecol. Manage. 67, 440-454. doi: 10.2111/REM-D-13-00074.1

Chambers, J. C., Pyke, D. A., Maestas, J. D., Pellant, M., Boyd, C. S., Campbell, S. B., et al. (2014c). Using Resistance and Resilience Concepts to Reduce Impacts of Invasive Annual Grasses and Altered Fire Regimes on the Sagebrush Ecosystem and Greater Sage-Grouse: A Strategic Multi-Scale Approach. United States Department of Agriculture, Forest Service, Rocky Mountain Research Station.

Coates, P. S., Ricca, M. A., Prochazka, B. G., Brooks, M. L., Doherty, K. E., Kroger, T., et al. (2016). Wildfire, climate, and invasive grass interactions negatively impact an indicator species by reshaping sagebrush ecosystems. Proc. Natl. Acad. Sci. U.S.A. 113, 12745-12750. doi: 10.1073/pnas.1606 898113

Connelly, J. W., Schroeder, M. A., Sands, A. R., and Braun, C. E. (2000). Guidelines to manage sage grouse populations and their habitats. Wildlife Soc. Bull. 28, 967-985. doi: 10.2458/azu_rangelands_v28i3_schroeder

Cook, B. I., Ault, T. R., and Smerdon, J. E. (2015). Unprecedented 21st century drought risk in the American Southwest and Central Plains. Sci. Adv. 1:e1400082-e1400082. doi: 10.1126/sciadv.1400082

Crawford, J. A., Olson, R. A., West, N. E., Mosley, J. C., Schroeder, M. A., Whitson, T. D., et al. (2004). Ecology and management of sage-grouse and sage-grouse habitat. J. Range Manage. 57, 2-19. doi: 10.2307/4003949

Crist, M. R., Chambers, J. C., Phillips, S. L., Prentice, K. L., and Wiechman, L. A. (2019). Science Framework for Conservation and Restoration of the Sagebrush Biome: Linking the Department of the Interior's Integrated Rangeland Fire Management Strategy to Long-Term Strategic Conservation Actions. Part 2. Management applications. doi: 10.2737/RMRS-GTR-389

D'Antonio, C. M., and Thomsen, M. (2004). Ecological resistance in theory and practice. Weed Tech. 18, 1572-1577. doi: 10.1614/0890037X(2004)018[1572:ERITAP]2.0.CO;2

Davidson, E. A., and Janssens, I. A. (2006). Temperature sensitivity of soil carbon decomposition and feedbacks to climate change. Nature 440, 165-173. doi: 10.1038 /nature 04514

Glick, P., Stein, B., and Edelson, N. A. (2010). Scanning the Conservation Horizon: A Guide to Climate Change Vulnerability Assessment. Washington DC: National Wildlife Federation.

Grimm, V., and Wissel, C. (1997). Babel, or the ecological stability discussions: an inventory and analysis of terminology and a guide for avoiding confusion. Oecologia 109, 323-334. doi: 10.1007/s004420050090

Gutschick Vincent, P., and BassiriRad, H. (2003). Extreme events as shaping physiology, ecology, and evolution of plants: toward a unified definition and evaluation of their consequences. N. Phytol. 160, 21-42. doi: 10.1046/j.1469-8137.2003.00866.x

Hamlet, A. F., Salathé, E. P., and Carrasco, P. (2010). Statistical Downscaling Techniques for Global Climate Model Simulations of Temperature and Precipitation With Application to Water Resources Planning Studies. Chapter 4. in Final Report for the Columbia Basin Climate Change Scenarios Project. (Seattle, WA: Climate Impacts Group, Center for Science in the Earth System, Joint Institute for the Study of the Atmosphere and Ocean, University of Washington).

Herrick, J. E., Brown, J. R., Bestelmeyer, B. T., Andrews, S. S., Baldi, G., Davies, J., et al. (2012). Revolutionary land use change in the 21st Century: is (Rangeland) science relevant? Rangeland Ecol. Manage. 65, 590-598. doi: 10.2111/REM-D-11-00186.1

Hirota, M., Holmgren, M., Van Nes, E. H., and Scheffer, M. (2011). Global resilience of tropical forest and savanna to critical transitions. Science 334, 232-235. doi: 10.1126/science. 1210657

Holling, C. S. (1973). Resilience and stability of ecological systems. Ann. Rev. Ecol. Syst. 4, 1-23. doi: 10.1146/annurev.es.04.110173.000245 
Huang, J., Li, Y., Fu, C., Chen, F., Fu, Q., Dai, A., et al. (2017). Dryland climate change: recent progress and challenges. Rev. Geophys. 55, 719-778. doi: 10.1002/2016RG000550

Jones, M. O., Allred, B. W., Naugle, D. E., Maestas, J. D., Donnelly, P., Metz, L. J., et al. (2018). Innovation in rangeland monitoring: annual, $30 \mathrm{~m}$, plant functional type percent cover maps for U.S. rangelands, 1984-2017. Ecosphere 9:e02430. doi: 10.1002/ecs2.2430

Kildisheva, O. A., Erickson, T. E., Merritt, D. J., and Dixon, K. W. (2016). Setting the scene for dryland recovery: an overview and key findings from a workshop targeting seed-based restoration. Restor. Ecol. 52, S36-S42. doi: $10.1111 /$ rec. 12392

Knick, S. T., Hanser, R. F. M., Pyke, D. A., Wisdom, M. J., Finn, S. P., Rinkes, E. T., et al. (2011). "Ecological Influence and Pathways of Land Use in Sagebrush," in Greater Sage-Grouse: Ecology and Conservation of a Landscape Species and Its Habitats. Studies in Avian Biology Vol. 38, eds S. T. Knick and J. W. Connelly (Berkeley, CA: University of California Press), 203-252. doi: 10.1525/california/9780520267114.003.0013

Lauenroth, W. K., and Bradford, J. B. (2006). Ecohydrology and the partitioning AET between transpiration and evaporation in a semiarid steppe. Ecosystems 9 , 756-767. doi: 10.1007/s10021-006-0063-8

Maestas, J. D., Campbell, S. B., Chambers, J. C., Pellant, M., and Miller, R. F. (2016). Tapping soil survey information for rapid assessment of sagebrush ecosystem resilience and resistance. Rangelands 38, 120-128. doi: $10.1016 /$ j.rala.2016.02.002

Manier, D. J., Wood, D. J. A., Bowen, Z. H., Donovan, R. M., Holloran, M. J., Juliusson, L. M., et al. (2013). Summary of Science, Activities, Programs, and Policies That Influence the Rangewide Conservation of Greater Sage-Grouse (Centrocercus urophasianus). U.S. Geological Survey Open-File Report 2013-1098.

Maurer, E. P., Brekke, L., Pruitt, T., and Duffy, P. B. (2007). Fine-resolution climate projections enhance regional climate change impact studies. Eos Transac. AGU 88:504. doi: 10.1029/2007EO470006

Millar, C. I., Stephenson, N. L., and Stephens, S. L. (2007). Climate change and forests of the future: managing in the face of uncertainty. Ecol. Appl. 17, 2145-2151. doi: 10.1890/06-1715.1

Miller, D. A., and White, R. A. (1998). A conterminous united states multilayer soil characteristics dataset for regional climate and hydrology modeling. Earth Interact. 2, 1-26. doi: 10.1175/1087-3562(1998)002\&lt;0001:ACUSMS\&gt;2.3.CO;2

Moss, R. H., Edmonds, J. A., Hibbard, K. A., Manning, M. R., Rose, S. K., van Vuuren, D. P., et al. (2010). The next generation of scenarios for climate change research and assessment. Nature 463, 747-756. doi: 10.1038/nature08823

Noy-Meir, I. (1973). Desert ecosystems: environment and producers. Ann. Rev. Ecol. Syst. 4, 25-51. doi: 10.1146/annurev.es.04.110173.000325

Overpeck, J. T. (2013). The challenge of hot drought. Nature 503, 350-351. doi: $10.1038 / 503350 \mathrm{a}$

Palmquist, K. A., Schlaepfer, D. R., Bradford, J. B., and Lauenroth, W. K. (2016a). Mid-latitude shrub steppe plant communities: climate change consequences for soil water resources. Ecology 97, 2342-2354. doi: 10.1002/ecy.1457

Palmquist, K. A., Schlaepfer, D. R., Bradford, J. B., and Lauenroth, W. K. (2016b). Spatial and ecological variation in dryland ecohydrological responses to climate change: implications for management. Ecosphere 7:e01590-n/a. doi: $10.1002 /$ ecs2.1590

Paruelo, J. M., and Lauenroth, W. K. (1996). Relative abundance of plant functional types in grasslands and shrublands of North America. Ecol. Appl. 6, 1212-1224. doi: $10.2307 / 2269602$

Petrie, M. D., Wildeman, A. M., Bradford, J. B., Hubbard, R. M., and Lauenroth, W. K. (2016). A review of precipitation and temperature control on seedling emergence and establishment for ponderosa and lodgepole pine forest regeneration. For. Ecol. Manage. 361, 328-338. doi: 10.1016/j.foreco.2015.11.028

R Core Team (2016). R: A Language and Environment for Statistical Computing. R Foundation for Statistical Computing, Vienna, Austria. Available online at: http://www.R-project.org/

Rehfeldt, G. E., Crookston, N. L., Sáenz-Romero, C., and Campbell, E. M. (2012). North American vegetation model for land-use planning in a changing climate: a solution to large classification problems. Ecol. Appl. 22, 119-141. doi: 10.1890/11-0495.1
Reichstein, M., Bahn, M., Ciais, P., Frank, D., Mahecha, M. D., Seneviratne, S I., et al. (2013). Climate extremes and the carbon cycle. Nature 500, 287-295. doi: 10.1038/nature12350

Renne, R. R., Schlaepfer, D. R., Palmquist, K. A., Bradford, J. B., Burke, I. C., and Lauenroth, W. K. (2019). Soil and stand structure explain shrub mortality patterns following global change type-drought and extreme precipitation. Ecology. doi: 10.1002/ecy.2889. [Epub ahead of print].

Renwick, K. M., Curtis, C., Kleinhesselink, A. R., Schlaepfer, D., Bradley, B. A., Aldridge, C. L., et al. (2017). Multi-model comparison highlights consistency in predicted effect of warming on a semi-arid shrub. Glob. Change Biol. 24, 424-438. doi: 10.1111/gcb.13900

Roundy, B. A., Chambers, J. C., Pyke, D. A., Miller, R. F., Tausch, R. J., Schupp, E. W., et al. (2018). Resilience and resistance in sagebrush ecosystems are associated with seasonal soil temperature and water availability. Ecosphere 9:e02417. doi: 10.1002/ecs2.2417

Saha, S., Moorthi, S., Pan, H.-L., Wu, X., Wang, J., Nadiga, S., et al. (2010). The NCEP climate forecast system reanalysis. Bull. Am. Meteorol. Soc. 91, 1015-1057. doi: 10.1175/2010BAMS3001.1

Schlaepfer, D. R., and Andrews, C. A. (2018). rSFSW2: Simulation Framework for SOILWAT2. R package version 3.0.0.

Schlaepfer, D. R., Bradford, J. B., Lauenroth, W. K., Munson, S. M., Tietjen, B., Hall, S. A., et al. (2017). Climate change reduces extent of temperate drylands and intensifies drought in deep soils. Nat. Commun. 8:14196. doi: 10.1038/ncomms14196

Schlaepfer, D. R., Lauenroth, W. K., and Bradford, J. B. (2012). Effects of ecohydrological variables on current and future ranges, local suitability patterns, and model accuracy in big sagebrush. Ecography 35, 374-384. doi: 10.1111/j.1600-0587.2011.06928.x

Schlaepfer, D. R., Lauenroth, W. K., and Bradford, J. B. (2014). Natural regeneration processes in big sagebrush (Artemisia tridentata). Rangeland Ecol. Manage. 67, 344-357. doi: 10.2111/REM-D-13-00079.1

Schlaepfer, D. R., and Murphy, R. (2018). rSOILWAT2: An Ecohydrological Ecosystem-Scale Water Balance Simulation Model. R package version 2.3.2.

Seager, R., and Vecchi, G. A. (2010). Greenhouse warming and the 21st century hydroclimate of southwestern North America. Proc. Natl. Acad. Sci. U.S.A. 107, 21277-21282. doi: 10.1073/pnas.0910856107

Seidl, R., Spies, T. A., Peterson, D. L., Stephens, S. L., and Hicke, J. A. (2016). REVIEW: searching for resilience: addressing the impacts of changing disturbance regimes on forest ecosystem services. J. Appl. Ecol. 53, 120-129. doi: 10.1111/1365-2664.12511

Shriver, R. K., Andrews, C. M., Pilliod, D. S., Arkle, R. S., Welty, J. L., Germino, M. J., et al. (2018). Adapting management to a changing world: warm temperatures, dry soil, and inter-annual variability limit restoration success of a dominant woody shrub in temperate drylands. Glob. Change Biol. 24, 4972-4982. doi: $10.1111 /$ gcb. 14374

Smith, M. D. (2011). The ecological role of climate extremes: current understanding and future prospects. J. Ecol. 99, 651-655. doi: 10.1111/j.1365-2745.2011.01833.x

Snyder, K. A., Evers, L., Chambers, J. C., Dunham, J., Bradford, J. B., and Loik, M. E. (2018). Effects of changing climate on the hydrological cycle in cold desert ecosystems of the great Basin and Columbia Plateau. Rangeland Ecol. Manage. 72, 1-2. doi: 10.1016/j.rama.2018.07.007

Soil Survey Staff (2014). Keys to Soil Taxonomy, 12th Edn. Washington, DC: USDA-Natural Resources Conservation Service.

Stein, B. A., Glick, P., Edelson, N., and Staudt, A. (2014). ClimateSmart Conservation: Putting Adaption Principles Into Practice. National Wildlife Federation.

Stocker, T. F., Qin, D., Plattner, G. K., Tignor, M., Allen, S. K., Boschung, J., et al. (2013). IPCC, 2013: Climate Change 2013: the Physical Science Basis. Contribution of working group I to the fifth assessment report of the intergovernmental panel on climate change.

Taylor, K. E., Stouffer, R. J., and Meehl, G. A. (2012). An overview of CMIP5 and the experiment design. Bull. Am. Meteorol. Soc. 93, 485-498. doi: 10.1175/BAMS-D-11-00094.1

Tietjen, B., Schlaepfer, D. R., Bradford, J. B., Lauenroth, W. K., Hall, S. A., Duniway, M. C., et al. (2017). Climate change-induced vegetation shifts lead to more ecological droughts despite projected rainfall increases in many global temperate drylands. Glob. Change Biol. 23, 2743-2754. doi: 10.1111/gcb.13598 
Tohver, I. M., Hamlet, A. F., and Lee, S.-Y. (2014). Impacts of 21st-century climate change on hydrologic extremes in the pacific northwest region of North America. J. Am. Water Resour. Assoc. 50, 1461-1476. doi: 10.1111/jawr. 12199

Ummenhofer, C. C., and Meehl, G. A. (2017). Extreme weather and climate events with ecological relevance: a review. Philos. Transac. R. Soc. 372, 1-13. doi: $10.1098 /$ rstb. 2016.0135

U. S. National Centers for Environmental Prediction (2010a). NCEP Climate Forecast System Reanalysis (CFSR) 6-Hourly Products, January 1979 to December 2010. Dataset ds093.0 published by the CISL Data Support Section at the National Center for Atmospheric Research, Boulder, CO, Available online at: http://dss.ucar.edu/datasets/ds093.0/ (accessed Jul 10, 2012).

U. S. National Centers for Environmental Prediction (2010b). NCEP Climate Forecast System Reanalysis (CFSR) Selected Hourly Time-Series Products, January 1979 to December 2010. Dataset ds093.1 published by the CISL Data Support Section at the National Center for Atmospheric Research, Boulder, CO. Available online at: http://dss.ucar.edu/datasets/ds093.1/ (accessed Jul 10, 2012).

Vicente-Serrano, S. M., Gouveia, C., Camarero, J. J., Beguería, S., Trigo, R., López-Moreno, J. I., et al. (2013). Response of vegetation to drought timescales across global land biomes. Proc. Natl. Acad. Sci. U.S.A. 110, 52-57. doi: $10.1073 /$ pnas. 1207068110

Wang, L., D’Odorico, P., Evans, J. P., Eldridge, D. J., McCabe, M. F., Caylor, K. K., et al. (2012). Dryland ecohydrology and climate change: critical issues and technical advances. Hydrol. Earth Syst. Sci. 16, 2585-2603. doi: 10.5194/hess-16-2585-2012

West, N. E. (2000). Synecology and Disturbance Regimes of Sagebrush Steppe Ecosystems. USDI Bureau of Land Management, 15-26.

Williams, M., and Friggens, M. (2017). Vulnerability Assessment of Sagebrush Ecosystems: Four Corners and Upper Rio Grande Regions of the Southern Rockies Landscape Conservation Cooperative. Final Report for Southern Rockies Landscape Conservation Cooperative. USDA Forest Service, Rocky Mountain Research Station. Available online at: https://www.sciencebase.gov/catalog/ item/56a79ee6e4b0b28f1184d937

Zhang, X., Wan, H., Zwiers Francis, W., Hegerl Gabriele, C., and Min, S.K. (2013). Attributing intensification of precipitation extremes to human influence. Geophys. Res. Lett. 40, 5252-5257. doi: 10.1002/grl.51010

Conflict of Interest: The authors declare that the research was conducted in the absence of any commercial or financial relationships that could be construed as a potential conflict of interest.

Copyright (c) 2019 Bradford, Schlaepfer, Lauenroth, Palmquist, Chambers, Maestas and Campbell. This is an open-access article distributed under the terms of the Creative Commons Attribution License (CC BY). The use, distribution or reproduction in other forums is permitted, provided the original author(s) and the copyright owner(s) are credited and that the original publication in this journal is cited, in accordance with accepted academic practice. No use, distribution or reproduction is permitted which does not comply with these terms. 